"Bank capitalization and bank performance: a comparative analysis using accounting- and market-based measures"

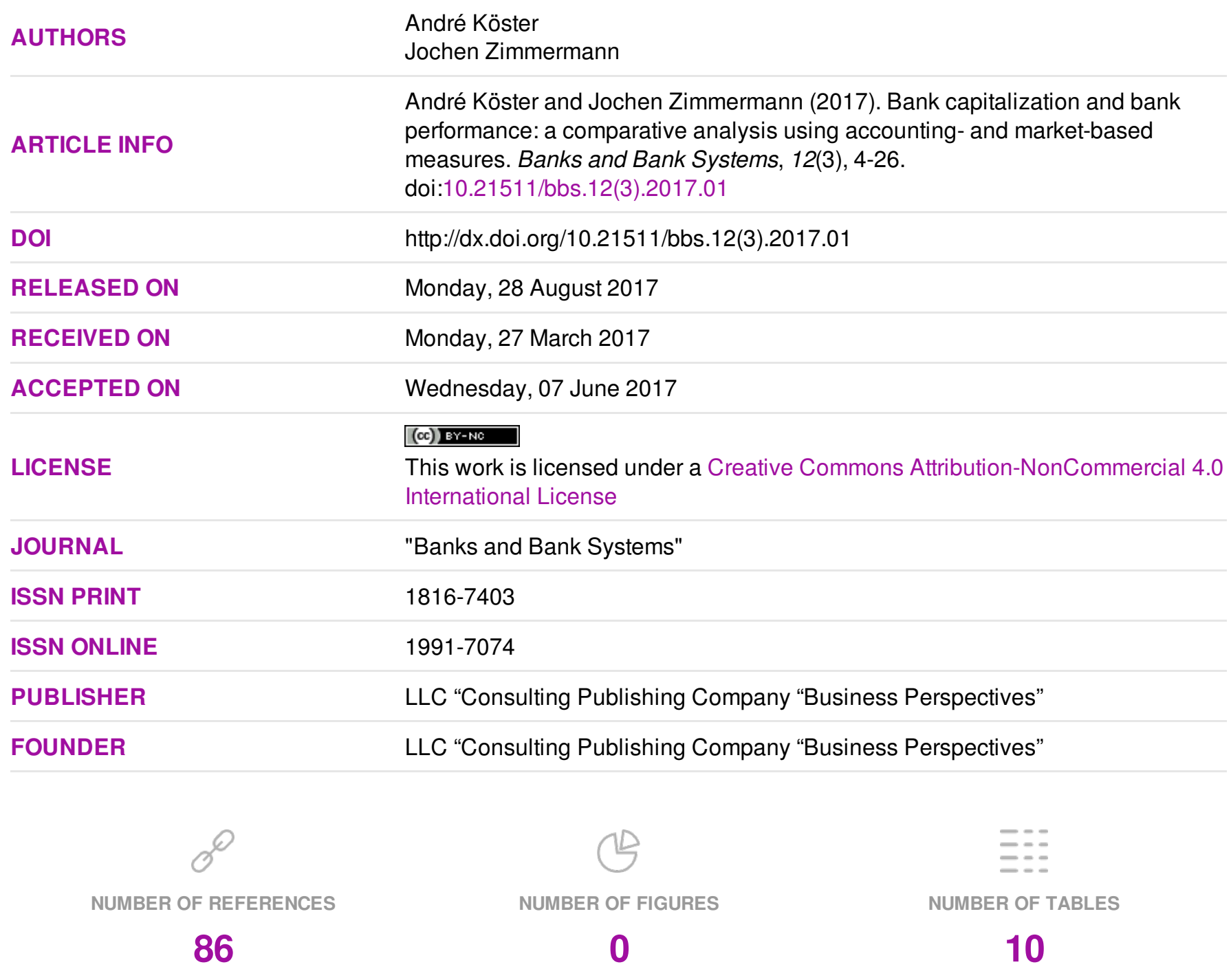

(C) The author(s) 2022. This publication is an open access article. 


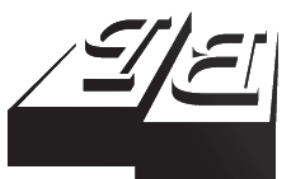

BUSINESS PERSPECTIVES

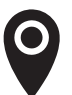

LLC “CPC "Business Perspectives" Hryhorii Skovoroda lane, 10, Sumy, 40022, Ukraine

www.businessperspectives.org

Received on: $27^{\text {th }}$ of March, 2017 Accepted on: $7^{\text {th }}$ of June, 2017

(C) André Köster, Jochen

Zimmermann, 2017

André Köster, Researcher, Department of Accounting and Control, University of Bremen, Germany.

Jochen Zimmermann, Full professor, Department of Accounting and Control, University of Bremen, Germany.

\title{
BANK CAPITALIZATION AND BANK PERFORMANCE: A COMPARATIVE ANALYSIS USING ACCOUNTING- AND MARKET-BASED MEASURES
}

\begin{abstract}
This paper examines performance outcomes of capitalization in the European bank market. Using a Europe-an sample with 2,504 firm-year observations for the years 1992-2012, the authors analyze the effect of capitalization as used by the financial regulators on bank risk and bank profitability with alternative accounting- and marketbased measures. All accounting-based measures consistently show that higher capitalization reduces bank risk and is associated with increased profitability. Contrary to this, market-based risk measures show higher bank risk implying possibly different risk assessment by capital market participants. Our results are corroborated by an ex post analysis of bank performance in times of crisis. Higher capitalized banks have fared better after the crisis in respect of profitability and risk.
\end{abstract}

Keywords

bank capitalization, bank performance, accounting- and market-based measures

JEL Classification G21, G32

\section{INTRODUCTION}

During the last financial crisis governments in many European member states had to bail out or nationalize some of their major banks to maintain the stability of financial markets and to prevent a systemic shock for the economy as a whole. In the aftermath of these events support has grown for more bank regulation including, in effect, a higher bank capitalization to prevent bank failures and avoid bailouts with taxpayers' funds in the future. The effects of bank capitalization on bank performance, particularly risk and profitability, are still debated both in theory and practice. Theoretical models and empirical studies provide mixed results. However, without detailed knowledge of the effects of bank capitalization on performance, regulators cannot gauge the effects of their regulatory actions on individual institutions and the system as a whole.

With respect to bank risk, theoretical analyses of Kareken and Wallace (1978), Dothan and Williams (1980), Flannery (1989) or Furlong and Keeley (1989) show that bank capital regulation improves effects of governmental safety nets and discourages bank risk-taking. However, Kahane (1977) and Koehn and Santomero (1980) show that banks compensate the associated costs of stricter capital requirements by increased risk-taking. Empirical studies find that capital regulation in 
banking has been effective in increasing capital ratios without substantially shifting portfolios including off-balance sheet exposures towards riskier assets (Altunbas et al., 2007; Shrieves \& Dahl, 1992; Rime, 2001; Ediz, Michael, \& Perraudin, 1998). Capitalization requirements appear to be an attractive regulatory instrument, since they serve to reinforce the stability of the banking system without apparently distorting a bank's lending choices.

With respect to bank profitability, the impact of bank capitalization may be ambiguous. Higher levels of equity reduce risk, which in theory leads to a lower level of returns (Berger, 1995). However, high capital ratios could also decrease the cost of capital suggesting positive impacts on bank profitability (Molyneux, 1993). Early empirical research by Short (1979) and Bourke (1989) reports a positive connection of bank capital and bank profitability for banks in Canada, Western Europe and Japan. Using a similar setting, Molyneux \& Thornton (1992) provide evidence for an extended European sample of 18 countries, while Demirgüc-Kunt \& Huizinga (1999) report similar results for more global sample covering 80 countries. More recent evidence for the European bank market is provided by Athanasoglou, Delis \& Staikouras (2006) examining a sample of South Eastern European banks.

Empirical analyses are fraught by measurement problems. All elements of the performance measurement, st. risk namely, profitability and capital, are constructs that can build on accounting- or marketbased concepts. Accounting-based concepts are criticized for being anchored in past events, depending on open-ended accounting rules and being affected by earnings management. Market measurements are more timely and are based on the consensus of supply and demand, but they are simultaneously more volatile, and they are skewed in the presence of market bubbles or mispricing. It remains an open question which of the respective difficulties outweighs each other, both in a regulatory and managerial context.

The paper addresses two empirical questions. First, how did bank capitalization affect the constituent elements of bank performance, namely risk and profitability? Second, does the choice between accounting- and market-based measures matter? We focus on European (EU) banks in the years 1992-2012. As the period covered in this paper contains two crises with far-reaching consequences, the paper also attempts an expost examination of the performance of well capitalized banks during a market meltdown.

The remainder of this paper is organized as follows. Section 1 presents the related literature, develops the research questions and describes potential implications of increased capital requirements for banks. Section 2 explains the measurement of effects on bank risk and profitability using accounting and market-based variables, and it illustrates the regression models. Section 3 describes the sample and shows basic statistics. Sections 4 presents the empirical results; final section concludes the paper.

\section{CONCEPTUAL UNDERPINNINGS}

\subsection{Bank capitalization and bank performance: lessons from theory}

Despite a controversial debate on capital adequacy there is no consensus on the effects of bank capitalization in the presence of other regulation. In the presence of state guarantees or deposit insurance systems increased capital requirements can adopt the role of a limiting factor of bank risk-taking (Buser, Chen \& Kane, 1981; Kim \& Santomero, 1988; Berger, Herring, \& Szegö, 1995). Furlong \& Keely (1989) emphasize that higher capitalization reduces the option value of the deposit insurance. As a result, highly capitalized banks are less inclined to increase their portfolio risk.

Critics of stricter capital requirements fear that banks, and especially those which increase their capital to fulfill the new regulations, could adjust their portfolio structure towards a higher risk-return profile to compensate the costs of additional 
capital (Koehn \& Santomero, 1980; Blum, 1999; Jeitschko \& Jeung, 2005). In this case, stricter capital requirements would promote a higher bank risk-taking, which goes hand in hand with an increased risk of insolvency. Following Kahane (1977) and Koehn \& Santomero (1980), the reaction of banks to the new regulations could depend on the relative risk aversion of a bank or its managers. Their analysis implies that a bank with a sufficient level of risk tolerance will respond to a higher required capital by increasing the portfolio risk.

Calem \& Rob (1999) provide a reconciliation for these diverging effects of an increased bank capital by assuming an u-shaped link between capital and bank risk-taking. Using the example of a poor capitalized bank, the authors show that such a relationship would first imply a risk reducing effect of additional capital, which reverses when the bank fulfills the regulatory requirements.

A similar debate exists with respect to the effects of capitalization on profitability. When higher capital ratios reduce bank risk, investors demand risksensitive interest rates, and an increase in bank capital leads to a lower level of expected returns by investors (Berger, 1995). Furthermore, when stricter capital requirements are successful in restraining managerial risk appetite, this regulation should be accompanied by a lower-risk investment strategy with decreased levels of bank profits. Similar to this, the reduced risk from higher bank capital may also result in lower earnings, as it reduces the option value of mispriced deposit insurances (Shrieves \& Dahl, 1992; Berger, 1995).

However, bank capitalization may also have positive impacts on bank profitability. As higher capital ratios imply a decreased bank risk, investors require a lower risk premium, which also reduces the costs of capital (Molyneux, 1993). This refinancing advantage allows higher margins assuming unchanged risk preferences and, in this way, increases bank profitability. Furthermore, under favorable refinancing conditions, less risky investments already generate attractive returns, which avoid the investment in high-risk projects and possible allowances reducing bank profits. The monitoring hypothesis including works of Holmstrom \& Tirole (1997), Allen, Carletti \& Marquez (2011) and Mehran \& Thakor (2011) achieves similar results even though their work assumes a different mode of action. For them, higher capital increases the level borrower monitoring by the bank, thereby reducing the probability of default and, thus, bank profits.

\subsection{Accounting- and market-based models}

Both accounting- and market-based models are available to analyze the effect of bank capitalization on bank's risk, as well as on its profitability. Even though the application of these concepts is common in the finance research literature, their different characteristics and diverging merits and shortcomings are rarely taken into account. An analysis that integrates both approaches might not only render a comprehensive view on the effect of bank capitalization, but may also reveal possible differences.

Accounting-based measurements are the traditional concept in assessing profitability and risk, and early regulation also rested on accountingbased figures. The essential objective of mandated accounting is to ensure that companies release financial statement information that is relevant to the socio-economic context. This can mean that mandated accounting information is comparable across entities, adequately measured and providing an understanding of a firm's value (Caruana \& Pazarbasioglu, 2008). However, it can also mean that accounting serves as a means of capital maintenance, emphasizing prudence rather than information. Most national accounting standards, stemming from the latter tradition, measure assets and liabilities at their entry costs or their amortized costs (Trainar, 2008). This approach not only correlates with a higher degree of stability in a firm's balance sheet but also creates hidden reserves and liabilities that cannot be discovered by external investors. Throughout a business cycle, a historical cost valuation may lead to an undervaluation of the asset during an upturn, and conversely to an overstated asset value during the downturn (Caruana \& Pazarbasioglu, 2008). The reliance on past transaction prices also implies accounting values that are insensitive to more recent price signals. Inefficient decisions may result, as balance sheet entries do 
not reflect fundamental values (Plantin, Sapra \& Song, 2008). Indeed, a large part of the loans that triggered the recent financial crisis were shown at amortized costs (Tweedie, 2008).

Accounting information may have more shortcomings. First, the scope of accounting data is limited, as it misses further information that is contained in analyst reports or informal knowledge, e.g., a bank manager's reputation. Second, the low frequency of publication of accounting data also implies that it cannot reflect new information immediately. Third, accounting information is mostly backward looking in nature which is adverse when deriving a measure for a bank's future prospects (Knaup \& Wagner, 2012). Another important concern is a possible bias from a firm's accounting policy or earnings management.

In response to the shortcomings of accounting at historical cost, market prices have been integrated into the balance sheets to reflect more precisely the entries underlying economic value. Fair value accounting, which has recently been adopted in many European countries for consolidated financial reporting, tries to correct the insensitivity of historical cost accounting to new market information (Trainar, 2008).

Market prices may be a reasonable substitute for accounting figures. They can be used not only for the valuation of an entity's single asset, but also for an assessment of the entity itself. Agarwal \& Taffler (2007) emphasize that marked-based models counter most of the criticisms of accounting-based models. In efficient markets, stock prices reflect, apart from besides all information contained in accounting statements, further information that is available on the market. As market variables reflect future expected cash flows and are unlikely to be influenced by accounting policies they should be more appropriate for prediction purposes (Agarwal \& Taffler, 2007). Under standard conditions, market valuation should meet its objective of providing information about bank's true risk profile and promote market discipline (Caruana \& Pazarbasioglu, 2008). However, markets are subject to uncertainties and prices could rather reflect available liquidity than expected future cash flows (Allen \& Carletti, 2006).
In recent years, there has been a growing interest in using market-based information to measure bank risk, as the existing evidence suggests that the market does well in evaluating the risks at financial institutions (Knaup \& Wagner, 2012). The increasing focus on market forces can also be observed within the regulatory framework developed by the Basel Committee on Banking and Supervision, the Basel Accord (Distinguin, Rous \& Tarazi, 2006). Due to the increasing trading activities of banks and the associated market price risks, the Basel Committee extended its Basel I Accord of 1988 by adding the requirement of an explicit capital cushion for this type of risk (BIS, 1996). To determine the additional capital, banks are allowed to use, apart from the standardized method, proprietary in-house models that fulfill quantitative and qualitative criteria. The second Basel Convention attaches an even stronger importance to the market. Under Pillar 3 of this convention the Basel Committee seeks to encourage market discipline by developing a set of disclosure requirements, which will enable market participants to assess bank capital, risk exposure, risk assessment processes, and, hence, the capital adequacy of the institution (BIS, 2006). In this context, share prices should reflect a wide range of information and, therefore, the market's overall assessment of a bank (Knaup \& Wagner, 2012).

\section{RESEARCH DESIGN}

\subsection{Measuring bank risk}

Sophisticated risk measures such as value at risk, expected shortfall or the volatility of market values of assets are usually not available for archival research. For this reason researchers often use balance sheet based proxies for risk measures (Heid, Porath \& Stolz, 2004). As every proxy has different characteristics and limitations (Hancock, Laing, \& Wilcox, 1995), there is no consensus about which measure is the most suitable (Jokipii \& Milne, 2011). We, therefore, define a set of accounting-based risk measures covering a varying proportion of the overall bank risk.

Market-based risk proxies are also available. Capital market participants engage in information gathering about company's earnings pros- 
pects and risk. For this reason, share prices may already contain information which cannot be derived from the balance sheet or which has already been anticipated by market participants. Therefore, market prices could already indicate financial difficulties deduced from accounting information. At a later stage, we compare the properties and results of both measurement concepts.

The first accounting-based proxy for bank risk is the loan loss provision (LLP). We define loan loss provision as ratio of write-off on loans and total loans (Jahankhani \& Lynge, 1979). Even though this variable is an ex-post measure of credit risk, it can serve as a reasonable proxy for overall portfolio quality and, thus, the risk position of a bank. Regulatory authorities attach to them high importance as they have been one of the main reasons for bank failures (Crockett, 1996; Ashcraft, 2008).

The second measure to analyze bank risk is calculated as the ratio of risk-weighted assets and total assets (RWATA). This variable implies capital allocation between different types of risk as an important determinant of overall bank risk (Keeton, 1989). However, risk-weighted assets do not only reflect capital allocation, but also the portfolio's quality and risk (Jacques \& Nigro, 1997). As a shortcoming, this measure solely records one component of the overall risk, the credit risk, and discounts the market risk.

Our last risk proxy is of accounting origin, but may incorporate market information. The variable interest expenses (INT_EXP) is a cross-sectional risk measure (Demirgüc-Kunt \& Huizinga, 2004). Slightly modified, this measure is the ratio of total interest expenses and net sales. The underlying concept bases on the debtor's risk assessment by assuming that unprotected debtors demand an additional risk premium when bank risk rises. Banks that are considered to be safe should benefit from a reduced risk premium. However, this measure could be possibly distorted by the influence of state deposit insurance or implicit too-big-to-fail guarantees.

Following the common market-based approach to measure bank risk, we use the share price volatility. Share prices may already contain additional information from different sources, which can- not be derived from the balance sheet. In this context, higher volatility implies a higher uncertainty about a company's future earnings prospects and risk. We calculate the standard deviation of stock market returns. The variables SD_DRET and SD_ MRET measure the daily (e.g., Anderson \& Fraser, 2000; Konishi \& Yasuda, 2004) and monthly (Neuberger, 1991; Levine \& Zervos, 1996) volatility, respectively. Table 1 summarizes the accounting and market-based risk measures.

Table 1. Risk measures

\begin{tabular}{|c|c|c|}
\hline Measure & Origin & Definition \\
\hline LLP & Accounting & Loan Loss provisions / Total Loans \\
\hline RWATA & Accounting & Risk-weighted Assets / Total Assets \\
\hline INT_EXP & Accounting & $\begin{array}{l}\text { Total Interest Expenses / Net Sales } \\
\text { Or Revenues }\end{array}$ \\
\hline SD_DRET & Market & $\begin{array}{l}\text { Standard Deviation of Daily } \\
\text { returns (DRET) }\end{array}$ \\
\hline SD_MRET & Market & $\begin{array}{l}\text { Standard Deviation of Monthly } \\
\text { returns (MRET) }\end{array}$ \\
\hline
\end{tabular}

\subsection{Measuring bank profitability}

To measure bank profitability, we use standard variables commonly applied in empirical research. As before, we distinguish between accountingand market-based measures to disclose potential differences between both approaches.

The first accounting measure is the return on assets (ROA) being the ratio of net income and total assets, which is a widespread measure in empirical research to capture bank's profitability (Athanasoglou, Delis, \& Staikouras, 2006; Curry, Fissel, \& Hanweck, 2008). ROA reflects the management's ability to utilize the bank's financial and real investment resources to generate profits (Hassan \& Bashir, 2003). A comparable measure is the profit margin (PROFIT_MAR) as the ratio of earnings and revenues (Lee and Zumwalt, 1981). The profit margin captures not only firm's operating efficiency, but also reflects its market position, as well as the market characteristics themselves.

The last accounting measure return on equity (ROE) calculated as the ratio of earnings and book value of equity reflects the return on capital used in a business unit. This measure should be 
assessed with caution, since it indicates not only high (low) profitability, but also low (high) capitalization (Klomp \& de Haan, 2012). The choice of financing instruments influences mechanically the return on equity, which results in a lower ROE when a company decides to increase capital (Modigliani \& Miller, 1963).

Again, we compare accounting-based measures with market-based metrics. Since the theory of efficient capital markets suggests that the market return is a good measure to determine the market's assessment of corporate performance, we use the stock return as market-based measure. The stock returns are calculated on daily (M_DRET) and annual (ARET) basis capturing the investor's assessment and portfolio allocation in a more differentiated way. The daily returns are average values computed for each bank and year. Here again, share prices may already contain further information, e.g., from analyst reports, regarding a firm's profitability, which cannot be derived from a company's financial statement. As companies are obliged to publish corporate news that are relevant for share prices in form of ad hoc releases, share prices may constitute a more timely and comprehensive measure of corporate performance. Despite these merits, share prices may also be biased by rather reflecting available market liquidity than new information. Table 2 summarizes the accounting- and market-based profitability measures.

Table 2. Profitability measures

\begin{tabular}{l|l:l}
\hline Measure & \multicolumn{1}{|c}{ Origin } & \multicolumn{1}{c}{ Definition } \\
\hline ROA & Accounting & $\begin{array}{l}\text { Net Income / Total Assets } \\
\text { PROFIT_ }\end{array}$ \\
MAR & Accounting & $\begin{array}{l}\text { Net Income / Net Sales or } \\
\text { Revenues }\end{array}$ \\
\hdashline ROE & Accounting & Net Income / Common Equity \\
\hdashline M_DRET & Market & Average Daily Return \\
\hline ARET & Market & Annual Return \\
\hline
\end{tabular}

\subsection{Measuring the effect of bank capitalization}

The empirical analysis conceptually follows the CAMEL approach, which uses a set of variables originally developed by the International
Monetary Fund (IMF) to explain a company's economic performance. This set includes measures for capital, asset quality, management, earnings, as well as liquidity and is commonly used in empirical research (Berger \& Bouwman, 2013; Klomp \& de Haan, 2012). Among others, Cole \& White (2012) use this set of variables, as well as a measure for an investment in the property market to explain the failure of American banks in 2009. Klomp \& de Haan (2012) develop a similar setting for their investigation of 200 banks in 21 member states of the Organization for Economic Cooperation and Development (OECD).

To examine the effects of capital on bank performance, we follow Aggarwal \& Jacques (2001), Rime (2001) and Klomp \& De Haan (2012) and use simple and risk adjusted equity capital ratios. First, we define capitalization as regulatory bank capital and use it as the principal exogenous variable CAP. CAP is calculated as the ratio of Tier 1 capital and risk-weighted assets and in accordance with banking regulations. Tier 1 capital includes common shareholders' equity and qualifying preferred stock, less goodwill and other adjustments. Our second capital variable ETA addresses concerns of possible manipulation of regulatory capital by banks. Critics of risk-adjusted capital ratios fear an underestimation of risk-weighted assets to boost regulatory capital. Therefore, ETA represents a simple equity ratio that comprises all equity components and total assets as denominator.

A fixed set of control variables ensures a consistent setting that allows identifying the influence of bank capital, as well as differences between the different types of measures. Following recent empirical research, the model specification uses control variables to capture bank's size, liquidity and credit risk that are also ascribed to determine bank's performance, as well as its risk.

We examine the effects of capitalization on bank risk and profitability using panel data. Following Baltagi (2005) \& Hsiao (2006), panel data allow to control for individual heterogeneity, to reduce issues of associated multicollinearity and biased estimates and the specification of time dependent connections between dependent and independent variables. Our use of time series data raises methodological issues relating to the stationarity of the 
data, which have important implications for the econometric techniques employed and the respective results (Roberts, 2000). To encounter problems of possible spurious regressions due to deterministic and stochastic trends in economic data, we define firm fixed and random effects regression models.

We use the following two regression models to estimate the effects on risk (1) and profitability (2), respectively.

$R I S K_{i, t}=\beta_{0}+\beta_{1} C A P_{i, t} / E T A_{i, t}+\beta_{2} S \operatorname{SIZE}_{i, t}+$ $\beta_{3} B A D L O A N S_{i, t}+\beta_{4} L I Q_{i, t}+\beta_{5} K E E L E Y ' S Q_{i, t}+$ $\beta_{6} E F F_{i, t}+\beta_{7} B A S E R A T E_{i, t-1}+\beta_{8} G D P_{i, t-1}+$ $+\beta_{9} L \mathcal{O} O \operatorname{INDEX}_{i, t}+\varepsilon_{i, t}$,

$P R O F_{i, t}=\beta_{0}+\beta_{1} C A P_{i, t} / E T A_{i, t}+\beta_{2} \operatorname{SIZE}_{i, t}+$ $\beta_{3}$ BADLOANS $_{i, t}+\beta_{4}$ LIQ $_{i, t}+$ $+\beta_{5}$ KEELEY'S $Q_{i, t}+\beta_{6} E F F_{i, t}+$ $+\beta_{7}$ BASE RATE RAt,-1 $+\beta_{8} G D P_{i, t-1}+$ $+\beta_{9} L \mho O I N D E X_{i, t}+\varepsilon_{i, t}$,

where RISK $_{i, t}$ is either $L L P_{i, t}$, the ratio of loan loss provision and total loans in fiscal year $t$ and for firm $i$, or $R W A T A_{i, t}$ the ratio of risk-weighted assets and total assets in fiscal year $t$ and for firm $i$, or INT_EXP $P_{i, t}$, the ratio of total interest expenses and net sales in fiscal year $t$ and for firm $i$, or $\mathrm{SD}_{-} \mathrm{DRET}_{i, t}$, the daily return's standard deviation in fiscal year $t$ and for firm $i$, or SD_MRET ${ }_{i, t}$, the monthly return's standard deviation in fiscal year $t$ and for firm $i$.

$P R O F_{i, t}$ is either $R O A_{i, t}$, the ratio of net income and total assets in fiscal year $t$ and for firm $i$, or PROFIT_MAR ${ }_{i, t}$ the ratio of net income and net sales or revenues in fiscal year $t$ and for firm $i$, or $R O E_{i, t}$, the ratio of net income and common equity in fiscal year $t$ and for firm $i$, or M_DRET , the average daily return in fiscal year $t$ and for firm $i$, or $A R E T_{i, t}$, the annual return in fiscal year $t$ and for firm $i$.

$C A P_{i, t}$ is the ratio of Tier 1 capital and risk-weighted assets in fiscal year $t$ and for firm $i$; ETA $A_{i, t}$ is the ratio of common equity and total assets in fiscal year $t$ and for firm $i$; SIZE $E_{i, t}$ is the natural logarithm of totals assets in fiscal year $t$ and for firm $i$; $B A D L O A N S_{i, t}$ is the ratio of non-performing loans and total loans in fiscal year $t$ and for firm $i ; L I Q_{i, t}$ is the ratio of liquid assets and total assets in fiscal year $t$ and for firm $i$; KEELEY'S $Q_{i, t}$ is the ratio of the sum of market value of equity and book value of liabilities and total assets in fiscal year $t$ and for firm $i$; EFF $F_{i, t}$ is the ratio of non-interest expenses and revenues in fiscal year $\mathrm{t}$ and for firm $i$; BASERATE $_{i, t-1}$ is the base rate of the firm's home country in fiscal year $t-1$ and for firm $i ; G D P_{i, t-1}$ is the growth rate of the firm's home country gross domestic product in fiscal year $\mathrm{t}-1$ and for firm $i$; $L \& O I N D E X_{i, t}$ is the law and order in fiscal year $t-1$ and for firm $i$.

\subsection{Internal and external determinants of bank performance from the set of control variables}

\subsubsection{Internal determinants}

The first control variable is bank size that is commonly used to control for possible size effects. Larger banks are supposed to be less risky as they may benefit from a more diversified investment portfolio in conjunction with a sophisticated risk management. However, larger banks could also reveal a greater risk exposure due to their business model with a larger share of higher-risk investment banking activities. Bank size should be also negatively associated with bank profitability when increased diversification leads to lower credit risk exposure and, thus, lower returns (Athanasoglou, Delis, \& Staikouras, 2006). Furthermore, larger banks are usually characterized by a more comprehensive administrative body, partly due to stricter regulation, and diseconomies of scale may reduce profitability.

Bank regulation requires keeping a particular proportion of assets as a liquidity reserve to maintain financial stability and solvency. In recent years, bank regulators have emphasized liquidity risk as one major determinant of overall bank risk. As a consequence, banks are now obliged to fulfill new liquidity regulations. To capture a bank's ability to cover large withdrawals in times of financial distress, we define LIQ as a control variable. LIQ is calculated as the ratio of total investments and total assets. Total investment represents holdings of securities which directly or indirectly cre- 
ate a loan made by the bank and includes, among other things government securities, federal funds and high quality trading accounts securities. We expect a reducing influence of liquidity on bank risk for multiple reasons. First, high investments in government securities reduce the proportion of higher-risk assets and, thereby, the total portfolio's risk. Second, in times of financial distress with large cash withdrawals, higher holdings of liquid funds enable the bank's management to react more flexible without selling illiquid long-term assets. The effect of LIQ on bank profitability is ambiguous. On the one hand, the investment in safe securities generates a lower rate of return than granting credits and, thereby, reduces bank profitability. On the other hand, even though loans usually offer higher interests than government securities, these additional yields could be offset by higher write-offs which reduce bank profitability.

An analysis of the recent banking crises in the Group of Ten (G10) industrialized countries reveals non-performing loans as major reason for bank difficulties or failure (BIS, 2004). As the granting of credit is one essential function of banks, credit risk forms the most important component of overall bank risk. In this context, too lax lending policies do not only increase the total volume of granted loans, but also in particular the share of non-performing loans and, thereby, bank risk. We define our credit risk variable BADLOANS as ratio of non-performing loans and total loans. Since write-downs of credit claims reduce earnings, we expect a negative association between BADLOANS and our defined bank profitability measures. However, the relation of nonperforming loans and bank risk should be positive.

KEELEY'S Q is a modified market-to-book ratio commonly used to proxy a possible charter value effect (Keeley, 1990). A high market-to-book value stands for banks with a high charter value. As insolvent banks lose their earnings prospects, banks with high charter values might pursue a defensive investment strategy to maintain their charter value. For this reason, there should be a negative relation between charter value and the measures of bank risk (Gueyie \& van Lai, 2003).

According to Hughes et al. (1996) und Hughes \& Mester (1998), a bank's performance and risk can be determined by its operational efficiency. In this respect, Berger \& DeYoung (1997) refer to empirical research (e.g., Berger \& Humphrey, 1992; Wheelock \& Wilson, 1995; Barr \& Siems, 1997) suggesting that bankrupt financial institutions were characterized not only by problematic loans, but also by substantial cost inefficiency. DeYoung \& Whalen (1994) show that a decrease of the average cost efficiency precedes the increase of the average problem loans. Therefore, the average cost efficiency could serve as indicator of future concerns with respect to bank risk and profitability. Following Boyd, De Nicolò \& Jalal (2006) and Agoraki et al. (2011), we calculate our efficiency indicator as ratio of non-interest expenses and revenues.

\subsubsection{External determinants}

We include two macroeconomic variables that are supposed to have a significant influence on bank risk and profitability: base rate (BASE RATE) and GDP growth rate (GDP). Macroeconomic effects and the corresponding demand for money and credit influence the performance of financial institutions (De Haan, 2001; Gueyie \& van Lai, 2003; Athanasoglou, Delis, \& Staikouras, 2006). The effect of base rates on bank performance is ambiguous. With respect monetary policy, lower level of interest rates could induce higher bank risk-taking on their search for yield (De Nicolò et al., 2010). This issue is even more pressing for financial institutions with long-term liabilities and a high level of secure asset classes (Rajan, 2005). However, low interest rates could also imply a risk-reducing effect. With respect to profitability, Dell'Ariccia, Laeven \& Marquez (2011) argue that a lower level of interest rates also entails reduced refinancing costs, which could augment earnings when banks do not pass this advantage to their debtors. Furthermore, the lower refinancing rates enable banks to generate adequate return with less risky investments, which will have positive effects on bank risk.

The influence of economic growth on bank risk and profitability is manifold. On the one hand, a higher growth rate implies a rising demand for credit and consequently increasing profits. However, a higher volume of credits usually comes along with a higher risk leading to a reduced prof- 
itability when financed projects turn out to be unprofitable ex post. The influence of the economic condition remains considerably despite the trend towards a greater geographic diversification and larger use of financial engineering techniques to manage risk associated with business cycle forecasting (Athanasoglou, Delis, \& Staikouras, 2006).

To capture country specific effects and the legal environment in which a bank operates, we follow Laeven (2002) and Demirgüç-Kunt \& Detragiache (2002) and consider an index variable (L\&O INDEX) regarding the quality and enforcement of the legislative system. L\&O INDEX is the International Country Risk Guides (ICRG) Law and Order Index published by PRS Group. The index scale takes values between 0 and 6 whereby higher values indicate a higher quality (lower risk). Even though a country has a good legal system it might receive a low rating if these applicable standards are ignored (Zimmermann \& Werner, 2013).

All variables used in this analysis are winsorized at 1 percent level to count for outliers that could bias the results. The macroeconomic variables GDP and BASE RATE are lagged by one period since these effects are usually deferred.

\section{SAMPLE SELECTION AND DESCRIPTIVE STATISTICS}

This study analyzes the effects of capital adequacy for the European bank market from 1992-2012. To ensure a high data quality, the sample is limited to listed banks. The balance sheets, share prices as well as GDP growth rates are taken from Worldscope Database, missing GDP values from the IMF's database. We convert values in foreign currency using historical exchange rates at fiscal year end. Stock returns are calculated in terms of discrete returns on a yearly basis. In the event of several stock exchange listings, we use the home exchange's data.

Table 3 shows the whole data sample containing 17 countries with 145 banks and in total 2,504 bank year observations. The countries with the highest number of banks are Italy (33), Denmark (27) and Switzerland (13). Small countries as Slovakia or Hungary are less represented having only one stock listed bank with available information. A comparison of median and mean values reveals large differences in bank size. While 50 percent of all banks report a balance sheet total up to 13,448 billion EUR, the mean value is almost nine times

Table 3. Data sample and bank size

\begin{tabular}{|c|c|c|c|c|c|c|c|}
\hline Country & $\begin{array}{l}\text { No. } \\
\text { of banks }\end{array}$ & Bank years & Share & B/S mean* & $\begin{array}{c}\text { B/S } \\
\text { median* }\end{array}$ & B/S min.* & B/S max.* \\
\hline Austria & 8 & 148 & $5.9 \%$ & $28 . \sqcup 466$ & 6.812 & 399 & 213.166 \\
\hline Belgium & 2 & 39 & $1.6 \%$ & 280.567 & 257.330 & 57.154 & 647.027 \\
\hline Denmark & 27 & 488 & $19.5 \%$ & 12.340 & 661 & 49 & 475.495 \\
\hline Finland & 2 & 42 & $1.7 \%$ & 10.716 & 6.282 & 588 & 44.587 \\
\hline France & 9 & 150 & $6.0 \%$ & 381.096 & 111.684 & 3.071 & 2071.532 \\
\hline Germany & 9 & 161 & $6.4 \%$ & 285.628 & 143.040 & 3.978 & 2193.953 \\
\hline Greece & 11 & 176 & $7.0 \%$ & 22.834 & 14.730 & 147 & 1202.739 \\
\hline Hungary & 1 & 17 & $0.7 \%$ & 19.959 & 16.922 & 5.165 & 36.074 \\
\hline Ireland & 3 & 58 & $2.3 \%$ & 73.953 & 60.631 & 1.186 & 197.289 \\
\hline Italy & 33 & 513 & $20.5 \%$ & 63.066 & 16.023 & 488 & 1035.148 \\
\hline Luxembourg & 1 & 17 & $0.7 \%$ & 55.119 & 50.513 & 19.528 & 86.797 \\
\hline Netherlands & 2 & 31 & $1.2 \%$ & 295.381 & 222.816 & 8.180 & 1021.817 \\
\hline Portugal & 4 & 76 & $3.0 \%$ & 35.377 & 26.985 & 923 & 99.321 \\
\hline Slovakia & 1 & 16 & $0.6 \%$ & 7.780 & 7.378 & 4.440 & 11.224 \\
\hline Spain & 10 & 189 & $7.5 \%$ & 124.073 & 37.306 & 1.703 & 1249.871 \\
\hline Switzerland & 13 & 244 & $9.7 \%$ & 82.384 & 10.843 & 793 & 1489.094 \\
\hline United Kingdom & 9 & 139 & $5.6 \%$ & 514.602 & 250.816 & 12.709 & 2587.544 \\
\hline Total & 145 & 2.504 & $100 \%$ & 117.318 & 13.448 & 49 & 2587.544 \\
\hline
\end{tabular}

Note: ${ }^{\star}$ balance sheet total in million Euro (EUR). 
Table 4. Descriptive statistics

\begin{tabular}{|c|c|c|c|c|c|}
\hline Panel A: risk variables & Mean & Median & SD & Min. & Max. \\
\hline LLP & 0.0076 & 0.0052 & 0.0086 & -0.0032 & 0.0519 \\
\hline RWATA & 0.6203 & 0.6220 & 0.2432 & 0.0007 & 1.2764 \\
\hline INT_EXP & 0.4254 & 0.4153 & 0.1656 & 0.0366 & 0.9022 \\
\hline SD_DRET & 0.0180 & 0.0156 & 0.0117 & 0.0004 & 0.0703 \\
\hline SD_MRET & 0.0762 & 0.0636 & 0.0546 & 0.0014 & 0.3262 \\
\hline Panel B: profitability variables & Mean & Median & SD & Min. & Max. \\
\hline $\mathrm{ROA}$ & 0.0057 & 0.0055 & 0.0086 & -0.0382 & 0.0437 \\
\hline PROFIT_MAR & 0.0800 & 0.0829 & 0.1177 & -0.5040 & 0.4624 \\
\hline ROE & 0.0992 & 0.1008 & 0.1410 & -0.5677 & 0.5819 \\
\hline M_DRET & 0.0002 & 0.0003 & 0.0014 & -0.0044 & 0.0046 \\
\hline ARET & 0.0746 & 0.0578 & 0.3686 & -0.7883 & 1.4293 \\
\hline Panel C: control variables & Mean & Median & SD & Min. & Max. \\
\hline CAP & 0.1109 & 0.0894 & 0.1054 & 0.0470 & 1.1230 \\
\hline ETA & 0.0687 & 0.0592 & 0.0394 & 0.0053 & 0.4752 \\
\hline SIZE & 16.4474 & 16.4143 & 2.2605 & 10.8808 & 20.7578 \\
\hline BADLOANS & 0.0284 & 0.0189 & 0.0337 & 0.0000 & 0.2474 \\
\hline LIQ & 0.2453 & 0.2296 & 0.1323 & 0.0146 & 0.7147 \\
\hline KEELEY'S Q & 1.0217 & 1.0098 & 0.0646 & 0.8893 & 1.5454 \\
\hline EFF & 0.8953 & 0.9319 & 0.1165 & 0.2597 & 1.0000 \\
\hline BASERATE & 0.0410 & 0.0375 & 0.0223 & 0.0050 & 0.1650 \\
\hline GDP & 0.0439 & 0.0416 & 0.0429 & -0.0995 & 0.2733 \\
\hline L\&O INDEX & 5.30 & 5.79 & 0.83 & 3.00 & 6.00 \\
\hline
\end{tabular}

Note $:$ LLP $=$ Loan Loss provisions / Total Assets, RWATA = Risk-weighted Assets / Total Loans, INT_EXP = Interest Expenses / Net Sales or Revenues, SD_DRET is the Standard Deviation of Daily Returns, SD_MRET is the Standard Deviation of Monthly Returns, ROA = Net Income $/$ Total Assets, PROFIT $=$ (Income before Tax + Total Interest Expenses) $/$ Total Assets, PROFIT_MAR = Net Income $/$ Net Sales or Revenues, ROE = Net Income / Common Equity , the variable MEAN_DRET is the average Daily Return per fiscal year and firm, ARET is the Annual Return, CAP = Tier-1-Capital / Risk-weighted Assets, ETA $=$ Common Equity $/$ Total Assets, SIZE $=\ln ($ Total Assets),LIQ $=$ Total Investments $/$ Total Assets, BADLOANS = Nonperforming Loans / Total Assets, KEELEY'S Q = Market Capitalization + Total Liabilities / Total Assets, EFF = Non-interest expenses / Net Sales or Revenues, BASERATE is the national base rate, GDP the annual gross domestic product growth rate and L\&O INDEX the Law and Order Index published by the International Country Risk Guide.

higher amounting to 117,318 billion EUR. These differences remain at the country level, and the largest can be observed for Denmark, France and Switzerland.

Table 4 reports the descriptive statistics for all banks within the period 1992-2012. While the accounting risk proxies RWATA and INT_EXP suggest a homogenous risk structure of European banks, the market-based risk variables indicate a greater risk exposure of some individual institutions. Comparable to this, the accounting-based profitability variables also show only small differences between mean and median values implying a uniform performance of the total bank sample. However, as for the market-based risk proxies, the market perspective reveals a different assessment of some bank's profitability, as there are some institutions benefiting from higher stock returns on annual. The descriptive statistics show a similar pattern for bank capitalization. Even though the average regulatory bank capital amounts to 11.1 percent, 50 percent of all banks only have a capitalization up to 8.9 percent.

The correlation matrix in Table 5 (see Appendix) shows for the accounting-based risk proxies LLP, RWATA and INT_EXP a negative and highly significant correlation with regulatory capital. The market-based measures SD_DRET and SD_ MRET are slightly negative, but there is no significant correlation. An examination of the correla- 
tion of capitalization and profitability indicates a positive link for all profitability variables irrespective of their origin. However, this relation is not significant for ROE, MEAN_DRET and ARET. The simple capital ratio shows except for LLP and RWATA a comparable correlation pattern. The connection between the macroeconomic variables BASE RATE and GDP and the accounting and market-based risk measures shows both positive and negative coefficients, which do not allow any conclusions. The same applies to all profitability measures. The correlation matrix already indicates two findings, first, based on accounting measures, there is an indication of a risk-reducing effect of capital and, second, irrespective of the measure's origin higher capital may increase profitability at the same time (see Table 5 in Appendix).

\section{EMPIRICAL RESULTS}

\subsection{Effects of capitalization on bank risk}

Table 6a (see Appendix) reports the fixed and random effects regression results for assessing bank risk. With a $\mathrm{R}^{2}$ between 24.5 and 41.6 percent all accounting- and market-based regressions explain a substantial amount of bank risk. The Hausman Test rejects the random effects model for all specifications. F-statistic values ranging from 7.21 to 20.70 imply individual effects on firm level.

The control variables mainly show the expected influence on bank risk. We find a risk reducing effect of liquidity and charter value. The negative and mostly significant coefficients for the accounting and market-based risk proxies suggest that large portfolios of liquid securities promote a lower level of bank risk by ensuring a bank's liquidity, as well as its ability to react flexibly to a changing economic environment. The results for BADLOANS indicate a risk-increasing effect of non-performing loans. Contrary to the expectations, the variable BASERATE controlling for the economic situation shows positive and highly significant coefficients. This observation confirms the general assumption of Dell'Ariccia, Laeven \& Marquez (2011) of a reduced bank risk in times of lower interest rates. When banks benefit from lower refinancing rates low risk assets with lower returns become more attractive. The remaining control variables GDP and L\&O Index deliver ambiguous results that do not allow determining a predominant influence on bank risk.

The results for our principal exogenous variable CAP confirm a risk reducing effect of bank capital for the accounting-based risk measures. We find lower provisions for loan loss for well-capitalized banks. This finding contradicts the general apprehension that banks could respond to increased capital requirements by adjusting their portfolio structure towards a higher risk-return profile, as this strategy should be accompanied by higher allowances on doubtful credit accounts in times of economic downturns that are covered by the investigation period.

The positive but insignificant coefficients for bank capital within the market-based risk model object the assumption that a higher amount of liability of shareholders promotes their willingness to monitor bank management behavior and improves thereby market discipline. This finding also contrasts the accounting-based risk proxy interest expenses INT_EXP that integrates a market component being the market's risk assessment. This proxy suggests that creditors assess a bank's risk and claim a higher risk premium for banks that are supposed to be more risky. The results for the market-based model provide evidence for the capital signaling hypothesis. As banks are required to maintain a capital ratio that is dependent on their asset quality, their capital may serve as a signal about the quality of their assets.

Consequently, investors may rely on each bank's capital levels as an indicator of the bank's asset risk (Akhigbe, Madura, \& Marciniak, 2012). In this context, a higher bank capital implies a higher bank risk.

Table 6b (see Appendix) shows the regressions results of the alternative simple capital ratio. For comparative purposes the results of our regulatory capital variable CAP are repeated and correspond to those reported in Table 6a. The reported outcome for ETA confirms the risk reducing effect of higher levels of capital. However, in comparison to the regulatory capital specification, negative and highly significant coefficients imply an even 
stronger impact on bank risk taking. Furthermore, the lower share price volatility within the marketbased regression specification suggests a higher reliance of capital market participants on simple equity ratios. These findings support the argumentation of Le Leslé \& Avramova (2012) that market participants adjust reported regulatory capital downwards to consider possible understatements of risk-weighted assets.

Our results for the accounting-based model are consistent with the small number of empirical papers addressing the link of bank capital regulation and bank risk. More recent empirical studies analyzing the effectiveness of capital adequacy regulations and the relationship between increases in banking capital and risk tend to find that capital regulation in banking has been effective in increasing capital ratios without substantially shifting their portfolio and off-balance sheet exposure towards riskier assets (Altunbas et al., 2007). Using a large sample of 1,800 US banks for the year 1984-1987, Shrieves \& Dahl (1992) find support for the risk-reducing effect of bank capital regulation for banks with relatively low capital levels. Further researches fail to provide evidence for a shift towards a high-risk profile. Rime (2001) examines the capital and risk behavior of a sample of Swiss banks during the period 1989-1995 by estimating a modified version of the model developed by Shrieves \& Dahl (1992). The results indicate that regulatory pressure induces banks to increase their capital without affecting their level of risk. Based on an analysis of the UK banking market over the period 1989-1995 Ediz, Michael \& Perraudin (1998) conclude that capital requirements appear to be an attractive regulatory instrument, since they serve to reinforce the stability of the banking system without apparently distorting a bank's lending choices.

\subsection{Effects on bank profitability}

Table 7a (see Appendix) shows the regression results for the analysis of profitability using fixed and random effects models. With $\mathrm{R}^{2} \mathrm{~s}$ between 21.0 and 37.1 percent for the accounting- and market-based measures, the regressions perform at a comparable level as the regressions on bank risk. Contrary to the risk regressions, the Hausman Test only rejects the random effects model for the market-based specifications. F-statistics ranging from 28.8 to 29.9 imply individual effects on firm level for the fixed effects specifications.

The results for the control variables provide unambiguous results confirming the predicted effects on bank profitability. SIZE has the assumed positive effect on profitability suggesting possible economies of scale and higher profits due to better investment opportunities or a broader access to capital markets. However, large banks do not benefit from higher stock market returns. Significant negative coefficients for the variable BADLOANS indicate the central role of non-performing loans as major determinant of bank profitability not only in times of crises. Regarding the macroeconomic control variables BASERATE and GDP, we find contradictory effects on profitability measures. A higher interest rate level has a positive impact on bank earnings for both types of profitability measures. While the positive and mostly significant coefficients for accounting measures confirm that a favorable economic environment is reflected in a bank's profit and loss accounts, market-based measures are negative by influenced by GDP growth. The negative values of LIQ within the accounting-based specification imply negative effects of large securities holdings.

The regression results for our principal exogenous variable CAP imply positive effects of bank capitalization on balance sheet-based profitability measures, as well as higher returns on capital markets. Regarding better capitalized banks, investors probably assume a more stable financial position that enhances the prospects of future profits. However, the most remarkable effect is the positive link to the accounting variables ROA, PROFIT_MAR and ROE, as a higher capitalization is generally accused to reduce a bank's profit.

Table 7b (see Appendix) shows the regressions results of the alternative simple capital ratio. As before, the results of our regulatory capital variable CAP are repeated for comparative purposes and correspond to those reported in Table 7a. The reported outcome for ETA confirms the profit increasing effect of higher levels of capital. Comparable to the risk specification the positive and highly significant coefficients imply an even stronger impact on bank profitability regarding 
Table 8. Performance of better capitalized banks during times of crises

\begin{tabular}{|c|c|c|c|c|c|c|}
\hline \multicolumn{7}{|c|}{ Pre-crisis bank capital (2004-2006) } \\
\hline CAP (average) & \multicolumn{6}{|c|}{0.0827} \\
\hline ETA (average) & \multicolumn{6}{|c|}{0.0629} \\
\hline \multicolumn{7}{|c|}{ Performance within crisis (2007-2011) } \\
\hline & \multicolumn{2}{|c|}{ high capital } & \multicolumn{2}{|c|}{ low capital } & \multicolumn{2}{|c|}{ t-values } \\
\hline & CAP & ETA & CAP & ETA & CAP & ETA \\
\hline \multicolumn{7}{|c|}{ Profitability } \\
\hline \multicolumn{7}{|l|}{ Accounting } \\
\hline $\mathrm{ROA}$ & 0.0031 & 0.0047 & 0.0017 & 0.0009 & -1.57 & $-4.56^{* * *}$ \\
\hline PROFIT_MAR & 0.0518 & 0.0765 & 0.0326 & 0.0237 & -1.35 & $-4.07 * * *$ \\
\hline $\mathrm{ROE}$ & 0.0364 & 0.0503 & 0.0404 & 0.0308 & 0.26 & -1.38 \\
\hline \multicolumn{7}{|l|}{ Market } \\
\hline M_DRET & -0.0070 & -0.0006 & -0.0008 & -0.0008 & -0.60 & -1.44 \\
\hline ARET & -0.1567 & -0.1374 & -0.2002 & -0.1930 & -1.25 & $-1.73^{*}$ \\
\hline \multicolumn{7}{|c|}{ Risk } \\
\hline \multicolumn{7}{|l|}{ Accounting } \\
\hline LLP & 0.0109 & 0.0101 & 0.0088 & 0.0086 & $-2.14^{* *}$ & $-1.69 *$ \\
\hline RWATA & 0.6287 & 0.6999 & 0.5912 & 0.4994 & $-1.69^{*}$ & $-10.24^{* * *}$ \\
\hline INT_EXP & 0.3711 & 0.3446 & 0.4164 & 0.4404 & $3.10^{* * *}$ & $7.75^{* * *}$ \\
\hline \multicolumn{7}{|l|}{ Market } \\
\hline SD_DRET & 0.0257 & 0.0225 & 0.0264 & 0.0275 & 0.58 & $4.20^{* * *}$ \\
\hline SD_MRET & 0.1001 & 0.0888 & 0.1035 & 0.1072 & 0.57 & $3.37^{* * *}$ \\
\hline
\end{tabular}

Note: the average capital ratio is the average TIER 1 capital ratio of all European banks within three years prior to the subprime crisis. On basis of these values, banks are classified into two groups. high capitalized and below average capitalized banks. We examine their performance during the subsequent years of crisis using our defined profitability measures. The values of the crisis performance are the average value of all banks within a group. The accounting- and market-based variables are calculated as follows. ROA $=$ Net Income $/$ Total Assets, PROFIT_MAR $=$ Net Income / Net Sales or Revenues, ROE $=$ Net Income / Common Equity ${ }_{\mathrm{t}-1}$, the variable M_DRET is the average Daily Return per fiscal year and firm, ARET is the Annual Return, LLP = Loan Loss provisions / Total Loans, RWATA = Risk-weighted Assets / Total Assets, INT_EXP = Interest Expenses / Net Sales or Revenues, SD_DRET is the Standard Deviation of Daily Returns, SD_MRET is the Standard Deviation of Monthly Returns.

the accounting-based measures. The lower stock market returns suggest that investors consider banks with higher simple capital rations as saver and, therefore, demand lower risk premiums.

Our results support the findings of previous studies using comparable measures of bank profitability to provide evidence for a positive link of bank capital and profitability. Focusing on bank market concentration, early research by Short (1979) reports a positive connection of bank capital and bank profitability for banks in Canada, Western Europe and Japan. Building on this research work the replication and extension of Bourke (1989) delivers comparable results. Using a similar setting, Molyneux \& Thornton (1992) provide evidence for an extended European sample of 18 countries for the years 1986-1989. Demirgüc-Kunt \& Huizinga (1999) use a large bank-level sample covering 80 countries in the years 1988-1995 to test a variety of determinants of bank profitability. More recent evidence for the European bank market is provided by Athanasoglou, Delis \& Staikouras (2006) examining a sample of South Eastern European banks for the years 1998-2002.

Possible implications of these finding are manifold. First, the decline in earnings might be rather a shortterm nature, which will be compensated by increasing profits in the long run. Second, as our results have shown, higher capital requirements reduce the risk appetite of a bank's shareholders and manage- 
ment. The lower-risk investment strategy entails a lower level of allowances and, thereby, enhances bank earnings. Third, since a high capital cushion reflects financial stability and earning power, wellcapitalized banks may benefit from an increased reputation. Positive effects that are even stronger in times of crisis might be reduced financing costs due to lower risk premiums, an increased customer confidence or a growing transaction volume.

\subsection{Additional analyses}

The examination period of 1992 to 2012 covers one crisis period, namely the recent subprime and sovereign debt crisis (2007-2011), which is also explicitly characterized as a financial market crisis. This allows an ex-post examination of bank performance in times of economic crises. We compare how banks with high and low capitalization have performed after the respective crises using the defined variables. We divide banks on basis of their 3-year-average pre-crises capitalization in terms of their risk-adjusted (CAP) and simple capital ratio (ETA) into two groups. First, banks disclosing capital above the total bank average are assigned to the group of wellcapitalized banks. Banks with a below-average capitalization form the low capital sample.

Regarding the analysis of bank profitability in times of crisis, the results of the crisis period show three major points. First, banks with a higher capital during the years prior to the crisis have a higher profitability in the years of a subsequent market slump. Second, well-capitalized banks disclose a higher profitability irrespective of the measurement approach. Banks show higher values for their accounting measures, but they also benefit from higher stock returns on daily and annual basis. In this case, both measurement approaches provide evidence that higher capitalization restrains bank risk ex-ante and helps banks ex-post to remain their financial stability even in a challenging economic environment. Third, the observed effects are even stronger for banks with higher levels of capital in terms of simple capital ratios.

Additionally, the risk analysis reveals two further interesting points. First, banks with higher capital benefit from lower financing costs and their share price volatility is lower as they are considered safer by investors resulting in reduced risk premiums. Second, banks with low capital have fewer allowances for non-performing loans and lower levels of risk-weighted assets. As allowances are subject to managerial discretion and reduce bank capital, management might be reluctant with impairments. Similarly, banks holding less capital are more likely to downgrade their riskweighted assets as lower levels imply a higher regulatory capital ratio.

\section{CONCLUSION}

The paper has examined the relation between bank performance and capitalization. Bank performance has been measured as bank risk and bank profitability using alternative accounting-based and marketbased specifications. A comparison of these specifications is helpful, as risk and profitability are both constructs, and their interpretation may differ in alternative specifications.

For the European banking market, accounting-based and market-based measures have shown somewhat differing results. First, accounting-based measures perform better in explaining the variation in risks between banks. Market-based metrics are not only pricing in information, but they are also subject to more fluctuations. Most importantly, the opposing results for the bank risk model raise the question of a differing risk assessment of market participants.

Second, across all measures a higher bank capitalization leads to a higher profitability. This is particularly noteworthy with respect to the accounting metrics as higher capital increases the denominator, depressing profitability from a technical perspective. Third, we have shown that accounting and marketbased performance measures can both capture the ex-post performance of banks after a financial crisis. In particular after the last financial crises, banks with a higher capitalization show better performance measures across the board. 


\section{REFERENCES}

1. Agarwal, V., \& Taffler, R. J. (2007). Comparing the performanceof market-based and accountingbased bankruptcyprediction models. Journal of Banking and Finance, 32(8), 1541-1551.

2. Agoraki, M.-E. K., Delis, M. D., \& Pasiouras, F. (2011). Regulations, competition and bank risk-taking in transition countries. Journal of Financial Stability, 7(1), 38-48.

3. Aggarwal, R., \& Jacques, K. T. (1998). Assessing the impact of prompt corrective action on bank capital and risk. Economic Policy Review, 4(3), 23-32.

4. Akhigbe, A., Madura, J., \& Marciniak, M. (2012). Bank capital and exposure to the financial crisis. Journal of Economics and Business, 64(5), 377-392. Retrieved from https://ideas.repec.org/a/eee/jebusi/v64y2012i5p377-392.html

5. Allen, F., \& Carletti, E. (2006). Mark-to-Market Accounting and Liquidity Pricing. Journal of Accounting and Economics, 45, 358-378.

6. Allen, F., Carletti, E., \& Marquez, R. (2011). Credit market competition and capital regulation. Review of Financial Studies, 24(4), 9831018. Retrieved from https:// academic.oup.com/rfs/articleabstract/24/4/983/1578448/CreditMarket-Competition-and-CapitalRegulation

7. Altunbas, Y., Carbo, S., Gardener, E. P., \& Molyneux, P. (2007). Examining the relationships between capital, risk and efficiency in European banking. European Financial Management, 13(1), 49-70.

8. Anderson, R. C., \& Fraser, D. R. (2000). Corporate control, bank risk taking, and the health of the banking industry. Journal of Banking \& Finance, 24(8), 13831398.

9. Ashcraft, A. B. (2008). Does the market discipline banks? New evidence from regulatory capital mix. Journal of Financial Intermediation, 17(4), 543-561.
10. Athanasoglou, P., Delis, M., \& Staikouras, C. (2006). Determinants of bank profitability in the South Eastern European region (Working Paper No. 10274). Athens: Bank of Greece.

11. Baltagi, B. H. (2005). Econometric analysis of panel data (3rd ed.). Chichester: Wiley.

12. Barr, R. S., \& Siems, T. F. (1997). Bank failure prediction using DEA to measure management quality. In R. S.Barr, R. V. Helgason \& J. L. Kennington. (Ed.). Interfaces in Computer Science and Operations Research (pp. 341-365). Boston: Kluwer Academic Publishers.

13. Berger, A. N. (1995). The relationship between capital and earnings in banking. Journal of Money, Credit and Banking, 27, 432-456.

14. Berger, A. N., \& Bouwman, C. H. S. (2013). How does capital affect bank performance during financial crises? Journal of Financial Economics, 109(1), 146-176. Retrieved from http://leeds-faculty.colorado.edu/ bhagat/Bank-Capital-Crisis-BergerBouwman.pdf

15. Berger, A. N., \& DeYoung, R. (1997) Problem loans and cost efficiency in commercial banks. Journal of Banking \& Finance, 21(6), 849-870.

16. Berger, A. N., Herring, R. J., \& Szegö, G. P. (1995). The role of capital in financial institutions. Journal of Banking \& Finance, 19(3), 393-430.

17. Berger, A. N., \& Humphrey, D. B. (1992).Measurement and efficiency issues in commercial banking. In Z. Griliches (Ed.). Measurement Issues in the Service Sectors (pp. 245-300), Chicago: University of Chicago Press.

18. Basel Committee on Banking Supervision (BCBS). (1996). Overview of the Amendment to the Capital Accord to incorporate Market Risks.

19. Basel Committee on Banking Supervision (BCBS). (2004). Bank Failures in Mature Economies, Working Paper No. 13. Basel: Bank for International Settlements.
20. Basel Committee on Banking Supervision (BCBS). (2006). International Convergence of Capital Measurement and Capital Standards. A Revised Framework Comprehensive Version.

21. Blum, J. M. (1999). Do capital adequacy requirements reduce risks in banking? Journal of Banking \& Finance, 23(5), 755-771.

22. Blum, J. M. (2008). Why 'Basel II' may need a leverage ratio restriction. Journal of Banking \& Finance, 32(8), 1699-1707. Retrieved from https://goo.gl/ QXVWjx

23. Bourke, P. (1989). Concentration and other determinants of bank profitability in Europe, North America and Australia. Journal of Banking \& Finance, 13(1), 65-79.

24. Boyd, J. H., De Nicolò, G., \& Jalal, A. M. (2006). Bank risk-taking and competition revisited: New theory and new evidence (Working Paper No. 06/297). Washington: International Monetary Fund. Retrieved from http://papers.ss-rn.com/sol3/ papers.cfm?abstract_id $=956761$

25. Buser, S. A., Chen, A. H., \& Kane, E. J. (1981). Federal Deposit Insurance, Regulatory Policy, and Optimal Bank Capital. The Journal of Finance, 36(1), 51-60.

26. Calem, P., \& Rob, R. (1999). The impact of capital-based regulation on bank risk-taking. Journal of Financial Intermediation, 8(4), 317-352.

27. Caruana, J., \& Pazarbasioglu, C. (2008). Revisiting valuation practices throughout the business cycle:Some symmetry is needed. Financial Stability Review, 12, 15-22.

28. Crockett, A. (1996). The theory and practice of financial stability. The Economist, 144(4), 531-568.

29. Curry, T. J., Fissel, G. S., \& Hanweck, G. A. (2008). Equity market information, bank holding company risk, and market discipline. Journal of Banking \& Finance, 32(5), 807-819. 
30. De Haan, L. (2001). The credit channel in the Netherlands. evidence from bank balance sheets, (Research Memorandum WO\&E No. 674/0129). Netherlands Central Bank.

31. Dell'Ariccia, G., Laeven, L., \& Marquez, R. (2011). Monetary policy, leverage, and bank risk-taking, (Discussion Paper No. DP8199). Washington: Centre for Economic Policy Research. Retrieved from http://papers.ssrn.com/sol3/ papers.-cfm?abstract_id $=1749820$

32. Demirgüç-Kunt, A., \& Detragiache, E. (2002). Does deposit insurance increase banking system stability? An empirical investigation. Journal of Monetary Economics, 49(7), 1373-1406.

33. Demirgüç-Kunt, A., \& Huizinga, H. (1999). Determinants of commercial bank interest margins and profitability. some international evidence. The World Bank Economic Review, 13(2), 379-408.

34. Demirgüc-Kunt, A., \& Huizinga, H. (2004). Market discipline and deposit insurance. Journal of Monetary Economics, 51, 375-399.

35. Demirgüc-Kunt, A., \& Huizinga, $H$. (2010). Bank activity and funding strategies. The impact on risk and returns. Journal of Financial Economics, 98(3), 626-650.

36. De Nicolò, G., Dell'Ariccia, G., Laeven, L., \& Valencia, F. (2010). Monetary Policy and Bank Risk Taking (IMF Staff Position Note No. 1009). Washington: International Monetary Fund. Retrieved from http://papers.ssrn.com/sol3/papers. cfm-?abstract_id $=1654582$

37. Distinguin, I., Rous, P., \& Tarazi, A. (2006). Market discipline and the use of stock market data to predict bank financial distress. Journal of Financial Services Research, 30, 151-176.

38. Dothan, U., \& Williams, J. (1980). Banks, bankruptcy, and public regulation. Journal of Banking \& Finance, 4(1), 65-87.

39. Ediz, T., Michael, I., \& Perraudin, W. (1998). The impact of capital requirements on UK bank behaviour. Economic Policy Review, 4(3), 15-22.
40. Fairfield, P. M., \& Yohn, T. L. (2001). Using Asset Turnover and Profit Marginto Forecast Changes in Profitability. Review of Accounting Studies, 6(4), 371-385.

41. Flannery, M. J. (1989). Capital regulation and insured banks choice of individual loan default risks. Journal of Monetary Economics, 24(2), 235-258.

42. Frank, M. Z., \& Goyal, V. K. (2009). Capital structure decisions. which factors are reliably important? Financial Management, 38(1), 1-37. Retrieved from https://goo. gl/69jA8H

43. Furlong, F. T., \& Keeley, M. C. (1989). Capital regulation and bank risk-taking. A note. Journal of Banking \& Finance, 13(6), 883-891.

44. Galloway, T. M., Lee, W. B., \& Roden, D. M. (1997). Banks' changing incentives and opportunities for risk taking. Journal of Banking \& Finance, 21(4), 509-527.

45. Gennotte, G., \& Pyle, D. (1991). Capital controls and bank risk. Journal of Banking \& Finance, 15(4), 805-824.

46. Gropp, R., \& Heider, F. (2010). The Determinants of Bank Capital Structure. Review of Finance, 14(4), 587-622. Retrieved from https:// academic.oup.com/rof/articleabstract/14/4/587/1588156/TheDeterminants-of-Bank-CapitalStructure

47. Gueyie, J.-P., \& van Lai, S. (2003). Bank moral hazard and the introduction of official deposit insurance in Canada. International Review of Economics \& Finance, 12(2), 247-273.

48. Hassan, K. M., \& Bashir, A.-H. M. (2003). Determinants of Islamic banking profitability (ERF Paper). Marocco: 10th ERF Annual Conference.

49. Holmstrom, B., \& Tirole, J. (1997). Financial intermediation, loanable funds, and thereal sector. The Quarterly Journal of Economics, 112(3), 663-691.

50. Hancock, D., Laing, A. J., \& Wilcox, J. A. (1995). Bank capital shocks. dynamic effects on securities, loans, and capital. Journal of Banking \& Finance, 19(3), 661-677.

51. Heid, F., Porath, D., \& Stolz, S. (2004). Does capital regulation matter for bank behavior? Evidence for German savings banks (EFMA 2004 Basel Meetings Paper). Frankfurt: Deutsche Bundesbank. Retrieved from http:// papers.ssrn.com/sol3/pa-pers. cfm?abstract_id $=493723$

52. Hsiao, C. (2006). Analysis of panel data ( $2^{\text {nd }}$ ed.). Cambridge: Cambridge University Press.

53. Hughes, J. P., Lang, W., Mester, L. J., \& Moon, C.-G. (1996). Efficient banking under interstate branching. Journal of Money, Credit and Banking, 28(4), 1045-1071.

54. Hughes, J. P., \& Mester, L. J. (1998). Bank capitalization and cost. Evidence of scale economies in risk management and signaling. Review of Economics and Statistics, 80(2), 314-325.

55. Jacques, K., \& Nigro, P. (1997). Risk-based capital, portfolio risk, and bank capital. A simultaneous equations approach. Journal of Economics and Business, 49(6), 533-547.

56. Jahankhani, A., \& Lynge, M. J. (1979). Commercial bank financial policies and their impact on market-determined measures of risk, (Faculty Working Paper No. 556.) Illinois: College of Commerce and Business Administration University of Illinois.

57. Jeitschko, T. D., \& Jeung, S. D. (2005). Incentives for risk-taking in banking - A unified approach. Journal of Banking \& Finance, 29(3), 759-777.

58. Jokipii, T., \& Milne, A. (2011). Bank capital buffer and risk adjustment decisions. Journal of Financial Stability, 7(3), 165-178.

59. Kahane, Y. (1977). Capital adequacy and the regulation of financial intermediaries. Journal of Banking \& Finance, 1(2), 207-218.

60. Kareken, J. H., \& Wallace, Neil (1978). Deposit insurance and bank regulation. A partialequilibrium exposition. Journal of Business, 51(3), 413-438. 
61. Keeley, M. C. (1990). Deposit insurance, risk, and market power in banking. The American Economic Review, 80(5), 1183-1200.

62. Keeton, W. R. (1989). The new risk-based capital plan for commercial banks. Federal Reserve Bank of Kansas City Economic Review, 74, 40-60.

63. Kim, D., \& Santomero, A. M. (1988). Risk in banking and capital regulation. The Journal of Finance, 43(5), 1219-1233.

64. Klomp, J., \& de Haan, J. (2012) Banking risk and regulation. Does one size fit all? Journal of Banking \& Finance, 36(12), 31973212. Retrieved from https://goo. gl/9xHy $4 \mathrm{c}$

65. Knaup, M., \& Wagner, W. (2012). A market-based measure of credit quality and banks'performance during the subprime crisis. Management Science, 58, 14231437. Retrieved from https://ideas. repec.org/p/tiu/tiucen/a6e8a0c800de-45b7-bb02-2afbed2c5c58. html

66. Koehn, M., \& Santomero, A. M. (1980).Regulation of bank capital and portfolio risk. The Journal of Finance, 35(5), 1235-1244.

67. Konishi, M., \& Yasuda, Y. (2004). Factors affecting bank risk taking. Evidence from Japan. Journal of Banking \& Finance, 28(1), 215-232.

68. Laeven, L. (2002). Bank risk and deposit insurance. The World Bank Economic Review, 16(1), 109-137.

69. Lee, C.-F., \& Zumwalt, J. K. (1981). Associations Between Alternative Accounting Profitability Measures and Security Returns. The Journal of Financial and Quantitative Analysis, 16(1), 71-93.
70. Le Leslé, V., \& Avramova, S. Y. (2012). Revisiting risk-weighted assets (Working Paper No. 1290). Washington: International Monetary Fund. Retrieved from https://www.imf.org/en/Publications/WP/Issues/2016/12/31/Revisiting-Risk-Weighted-Assets-25807

71. Levine, R., \& Zervos, S. (1996). Stock markets, banks, and economic growth, (Working Paper No. 1690). Washington: Worldbank.

72. Mehran, H., \& Thakor, A. (2011). Bank capital and value in the crosssection. Review of Financial Studies, 24(4), 1019-1067. Retrieved from https://www.newyorkfed.org/medialibrary/media/research/staff_reports/sr390.pdf

73. Modigliani, F., \& Miller, M. H. (1963). Corporate income taxes and the cost ofcapital. a correction. The American Economic Review, 53(3), 433-443.

74. Molyneux, P., \& Thornton, J. (1992) Determinants of European bank profitability. A note. Journal of Banking \& Finance, 16(6), 11731178.

75. Molyneux, P. (1993). Structure and performance in European Banking. Doctoral Dissertation, University of Wales, Bangor.

76. Neuberger, J. A. (1991). Risk and return in banking. Evidence from bank stock returns. Federal Reserve Bank of San Francisco Economic Review, 18-30.

77. Plantin, G., Sapra, H., \& Shin, H. S. (2008). Fair Value Accountingand Financial Stability. Financial Stability Review, 12, 85-94.

78. Rajan, R. G. (2005). Has financial development made the world riskier? (Working Paper 11728). Cambridge, MA: National Bureau of Economic Research.
79. Rime, B. (2001). Capital requirements and bank behaviour. Empirical evidence for Switzerland. Journal of Banking \& Finance, 25(4), 789-805.

80. Roberts, J. (2000). Spurious regression problems in the determinants of health care expenditure: A comment on Hitiris (1997). Applied Economics Letters, 7(5), 279-283.

81. Short, B. K. (1979).The relation between commercial bank profit rates and banking concentration in Canada, Western Europe, and Japan. Journal of Banking \& Finance, 3(3), 209-219.

82. Shrieves, R. E., \& Dahl, D. (1992) The relationship between risk and capital in commercial banks. Journal of Banking \& Finance, 16(2), 439-457.

83. Trainar, P. (2008). Valuation in Insurance and Financial Crisis. Financial Stability Review, 12, 101-113.

84. Tweedie, D. (2008). Bringing transparency to financial reporting. towards an improvedaccounting framework in the aftermath of the credit crisis. Financial Stability Review, 12, 115-120.

85. Wheelock, D. C., \& Wilson, P. W. (1995). Explaining bank failures. Deposit insurance, regulation, and efficiency. The Review of Economics and Statistics, 77(4), 689-700.

86. Zimmermann, Jochen; Werner, Jörg R. (2013). Regulating capitalism? The Evolution of Transnational Accounting Governance. Basingstoke: Palgrave Macmillan. Retrieved from https://secure. palgraveconnect.com/pc/doifinder/10.1057/9781137309280 


\section{APPENDIX}

Table 5. Correlation matrix of risk and profitability regression variables

\begin{tabular}{|c|c|c|c|c|c|c|c|c|c|c|c|c|c|c|}
\hline Panel A: risk & (1) & (2) & (3) & (4) & (5) & (6) & (7) & (8) & (9) & (10) & (11) & (12) & (13) & (14) \\
\hline \multirow{2}{*}{ LLP } & 1.0000 & & & & & & & & & & & & & \\
\hline & & & & & & & & & & & & & & \\
\hline \multirow{2}{*}{ RWATA } & 0.2232 & 1.0000 & & & & & & & & & & & & \\
\hline & 0.0000 & & & & & & & & & & & & & \\
\hline \multirow{2}{*}{ INT_EXP } & -0.1038 & -0.3407 & 1.0000 & & & & & & & & & & & \\
\hline & 0.0000 & 0.0000 & & & & & & & & & & & & \\
\hline \multirow{2}{*}{ SD_DRET } & 0.3643 & -0.1650 & 0.0733 & 1.0000 & & & & & & & & & & \\
\hline & 0.0000 & 0.0000 & 0.0004 & & & & & & & & & & & \\
\hline \multirow{2}{*}{ SD_MRET } & 0.3218 & -0.1537 & 0.0931 & 0.8615 & 1.0000 & & & & & & & & & \\
\hline & 0.0000 & 0.0000 & 0.0000 & 0.0000 & & & & & & & & & & \\
\hline \multirow{2}{*}{ CAP } & -0.0282 & -0.2406 & -0.1462 & -0.0181 & -0.0172 & 1.0000 & & & & & & & & \\
\hline & 0.3378 & 0.0000 & 0.0000 & 0.5348 & 0.5569 & & & & & & & & & \\
\hline \multirow{2}{*}{ ETA } & 0.0987 & 0.5796 & -0.5324 & -0.1259 & -0.1666 & 0.3115 & 1.0000 & & & & & & & \\
\hline & 0.0000 & 0.0000 & 0.0000 & 0.0000 & 0.0000 & 0.0000 & & & & & & & & \\
\hline \multirow{2}{*}{ BADLOANS } & 0.4664 & 0.0235 & -0.0106 & 0.3638 & 0.3703 & -0.0741 & -0.1422 & 1.0000 & & & & & & \\
\hline & 0.0000 & 0.4522 & 0.6734 & 0.0000 & 0.0000 & 0.0189 & 0.0000 & & & & & & & \\
\hline \multirow{2}{*}{ LIQ } & 0.0220 & -0.5208 & -0.0080 & 0.2182 & 0.1939 & -0.0114 & -0.0859 & -0.0461 & 1.0000 & & & & & \\
\hline & 0.2870 & 0.0000 & 0.6929 & 0.0000 & 0.0000 & 0.6910 & 0.0000 & 0.0670 & & & & & & \\
\hline \multirow{2}{*}{ KEELEY'S Q } & -0.1898 & 0.2023 & -0.1380 & -0.0077 & 0.0561 & -0.1069 & 0.0902 & -0.1157 & 0.0072 & 1.0000 & & & & \\
\hline & 0.0000 & 0.0000 & 0.0000 & 0.7059 & 0.0063 & 0.0002 & 0.0000 & 0.0000 & 0.7250 & & & & & \\
\hline \multirow{2}{*}{ EFF } & 0.1495 & 0.1432 & -0.2741 & 0.0324 & 0.0434 & 0.1259 & 0.2584 & -0.0064 & 0.1603 & -0.0123 & 1.0000 & & & \\
\hline & 0.0000 & 0.0000 & 0.0000 & 0.1575 & 0.0582 & 0.0000 & 0.0000 & 0.8055 & 0.0000 & 0.5885 & & & & \\
\hline \multirow{2}{*}{ BASERATE } & 0.0663 & -0.0361 & 0.2363 & -0.0762 & -0.0252 & -0.0998 & -0.0346 & -0.1098 & -0.0236 & 0.0156 & 0.0462 & 1.0000 & & \\
\hline & 0.0052 & 0.2064 & 0.0000 & 0.0009 & 0.2753 & 0.0005 & 0.1340 & 0.0001 & 0.3112 & 0.5042 & 0.0625 & & & \\
\hline \multirow{2}{*}{ GDP } & -0.1415 & 0.0078 & 0.0916 & -0.0997 & -0.0534 & 0.0020 & -0.0170 & -0.2397 & 0.0274 & 0.1840 & 0.0598 & 0.1196 & 1.0000 & \\
\hline & 0.0000 & 0.7825 & 0.0000 & 0.0000 & 0.0087 & 0.9444 & 0.4018 & 0.0000 & 0.1821 & 0.0000 & 0.0079 & 0.0000 & & \\
\hline \multirow{2}{*}{ L\&O INDEX } & 0.0851 & 0.0576 & 0.1642 & -0.1453 & -0.1696 & 0.0764 & 0.0468 & -0.1751 & -0.0227 & -0.1396 & 0.0892 & 0.1663 & 0.0308 & 1.0000 \\
\hline & 0.0000 & 0.0420 & 0.0000 & 0.0000 & 0.0000 & 0.0077 & 0.0191 & 0.0000 & 0.2636 & 0.0000 & 0.0001 & 0.0000 & 0.0944 & \\
\hline
\end{tabular}

Note: the variables are calculated as follows. LLP = Loan Loss provision / Total Loans, RWATA = Risk-weighted Assets / Total Assets, INT_EXP = Interest Expenses / Net Sales or Revenues, SD_DRET is the Standard Deviation of Daily Returns, SD_MRET is the Standard Deviation of Monthly Returns, CAP = Tier-1 Capital $/$ Risk-weighted Assets, ETA = Common Equity / Total Assets, SIZE = ln (Total Assets), LIQ = Total Investments / Total Assets, BADLOANS = Non-performing Loans / Total Assets, KEELEY'S Q = Market Capitalization + Total Liabilities / Total Assets, EFF = Non-interest expenses / Net Sales or Revenues, BASERATE is the national base rate, GDP the annual gross domestic product growth rate and L\&O INDEX the Law and Order Index published by the International Country Risk Guide. 
Table 5 (cont). Correlation matrix of risk and profitability regression variables

\begin{tabular}{|c|c|c|c|c|c|c|c|c|c|c|c|c|c|c|}
\hline Panel B: profit & $(1)$ & $(2)$ & (3) & (4) & (5) & (6) & $(7)$ & (8) & (9) & (10) & (11) & $(12)$ & (13) & (14) \\
\hline \multirow{2}{*}{ ROA } & 1.0000 & & & & & & & & & & & & & \\
\hline & & & & & & & & & & & & & & \\
\hline \multirow{2}{*}{ PROFIT_MAR } & 0.9193 & 1.0000 & & & & & & & & & & & & \\
\hline & 0.0000 & & & & & & & & & & & & & \\
\hline \multirow{2}{*}{ ROE } & 0.7621 & 0.7654 & 1.0000 & & & & & & & & & & & \\
\hline & 0.0000 & 0.0000 & & & & & & & & & & & & \\
\hline \multirow{2}{*}{ M_DRET } & 0.3179 & 0.3033 & 0.3496 & 1.0000 & & & & & & & & & & \\
\hline & 0.0000 & 0.0000 & 0.0000 & & & & & & & & & & & \\
\hline \multirow{2}{*}{ ARET } & 0.3327 & 0.3124 & 0.3432 & 0.9556 & 1.0000 & & & & & & & & & \\
\hline & 0.0000 & 0.0000 & 0.0000 & 0.0000 & & & & & & & & & & \\
\hline \multirow{2}{*}{ CAP } & 0.1198 & 0.1289 & 0.0012 & 0.0017 & 0.0183 & 1.0000 & & & & & & & & \\
\hline & 0.0000 & 0.0000 & 0.9660 & 0.9539 & 0.5357 & & & & & & & & & \\
\hline \multirow{2}{*}{ ETA } & 0.5040 & 0.4019 & 0.0683 & 0.0499 & 0.0567 & 0.3115 & 1.0000 & & & & & & & \\
\hline & 0.0000 & 0.0000 & 0.0007 & 0.0148 & 0.0062 & 0.0000 & & & & & & & & \\
\hline \multirow{2}{*}{ BADLOANS } & -0.5061 & -0.5060 & -0.4389 & -0.1546 & -0.1610 & -0.0741 & -0.1422 & 1.0000 & & & & & & \\
\hline & 0.0000 & 0.0000 & 0.0000 & 0.0000 & 0.0000 & 0.0189 & 0.0000 & & & & & & & \\
\hline \multirow{2}{*}{ LIQ } & 0.0254 & -0.0390 & 0.0656 & 0.0802 & 0.0672 & -0.0114 & -0.0859 & -0.0461 & 1.0000 & & & & & \\
\hline & 0.2097 & 0.0544 & 0.0013 & 0.0001 & 0.0013 & 0.6910 & 0.0000 & 0.0670 & & & & & & \\
\hline \multirow{2}{*}{ KEELEY'S Q } & 0.3343 & 0.2899 & 0.3192 & 0.2862 & 0.3176 & -0.1069 & 0.0902 & -0.1157 & 0.0072 & 1.0000 & & & & \\
\hline & 0.0000 & 0.0000 & 0.0000 & 0.0000 & 0.0000 & 0.0002 & 0.0000 & 0.0000 & 0.7250 & & & & & \\
\hline \multirow{2}{*}{ EFF } & 0.1756 & 0.0755 & 0.0845 & 0.1167 & 0.1312 & 0.1259 & 0.2584 & -0.0064 & 0.1603 & -0.0123 & 1.0000 & & & \\
\hline & 0.0000 & 0.0007 & 0.0002 & 0.0000 & 0.0000 & 0.0000 & 0.0000 & 0.8055 & 0.0000 & 0.5885 & & & & \\
\hline \multirow{2}{*}{ BASERATE } & 0.0744 & -0.0369 & 0.0874 & 0.1114 & 0.1294 & -0.0998 & -0.0346 & -0.1098 & -0.0236 & 0.0156 & 0.0462 & 1.0000 & & \\
\hline & 0.0013 & 0.1102 & 0.0002 & 0.0000 & 0.0000 & 0.0005 & 0.1340 & 0.0001 & 0.3112 & 0.5042 & 0.0625 & & & \\
\hline \multirow{2}{*}{ GDP } & 0.1640 & 0.1450 & 0.2184 & 0.0549 & 0.0736 & 0.0020 & -0.0170 & -0.2397 & 0.0274 & 0.1840 & 0.0598 & 0.1196 & 1.0000 & \\
\hline & 0.0000 & 0.0000 & 0.0000 & 0.0069 & 0.0004 & 0.9444 & 0.4018 & 0.0000 & 0.1821 & 0.0000 & 0.0079 & 0.0000 & & \\
\hline \multirow{2}{*}{ L\&O INDEX } & 0.0680 & 0.0434 & 0.0383 & 0.0775 & 0.0743 & 0.0764 & 0.0468 & -0.1751 & -0.0227 & -0.1396 & 0.0892 & 0.1663 & 0.0308 & 1.0000 \\
\hline & 0.0007 & 0.0299 & 0.0576 & 0.0001 & 0.0003 & 0.0077 & 0.0191 & 0.0000 & 0.2636 & 0.0000 & 0.0001 & 0.0000 & 0.0944 & \\
\hline
\end{tabular}

Note: the variables are calculated as follows. ROA $=$ Net Income $/$ Total Assets, PROFIT_MAR $=$ Net Income $/$ Net Sales or Revenues, ROE $=$ Net Income $/$ Common Equity , the variable M_DRET is the average Daily Return per fiscal year and firm, ARET is the Annual Return, CAP = Tier-1 Capital $/$ Risk-weighted Assets, ETA = Common Equity / Total Assets, SIZE $=$ ln (Total Assets), LIQ = Total Investments / Total Assets, BADLOANS = Non-performing Loans / Total Assets, KEELEY'S Q = Market Capitalization + Total Liabilities / Total Assets, EFF $=$ Non-interest expenses / Net Sales or Revenues, BASERATE is the national base rate, GDP the annual gross domestic product growth rate and L\&O INDEX the Law and Order Index published by the International Country Risk Guide. 
Table 6a. Regression results for accounting and market-based risk measures for the European bank market from 1992 to 2012

\begin{tabular}{|c|c|c|c|c|c|c|c|c|c|c|}
\hline \multirow{2}{*}{$\begin{array}{c}\text { Independent } \\
\text { variables }\end{array}$} & \multicolumn{2}{|c|}{ LLP (acc.) } & \multicolumn{2}{|c|}{ RWATA (acc.) } & \multicolumn{2}{|c|}{ INT_EXP (acc.) } & \multicolumn{2}{|c|}{ SD_DRET (mar.) } & \multicolumn{2}{|c|}{ SD_MRET (mar.) } \\
\hline & RE & FE & $\mathbf{R E}$ & FE & $\mathbf{R E}$ & $\mathrm{FE}$ & $\mathbf{R E}$ & FE & RE & FE \\
\hline \multirow{2}{*}{ CAP } & $-0.0048^{*}$ & -0.0035 & $-0.5561^{* * *}$ & $-0.5092 * * *$ & $-0.0699 * *$ & $-0.1226^{*}$ & -0.0024 & 0.0029 & 0.0013 & 0.0222 \\
\hline & $(-1.87)$ & $(-0.51)$ & $(-5.38)$ & $(-3.41)$ & $(-1.98)$ & $(-1.79)$ & $(-0.95)$ & $(0.82)$ & $(0.10)$ & $(1.08)$ \\
\hline \multirow{2}{*}{ SIZE } & $-0.0017^{* * *}$ & 0.0010 & $-0.0492 * * *$ & $-0.0470 * * *$ & $0.0255^{* * *}$ & 0.0239 & 0.0003 & $0.0071^{* * *}$ & 0.0019 & $0.0270^{* * *}$ \\
\hline & $(-5.24)$ & $(1.08)$ & $(-8.92)$ & $(-2.83)$ & $(6.52)$ & $(1.33)$ & $(0.73)$ & $(3.94)$ & $(1.17)$ & $(2.97)$ \\
\hline \multirow{2}{*}{ BADLOANS } & $0.1228 * * *$ & $0.1328 * * *$ & $-0.1988^{* *}$ & $-0.2490^{*}$ & $0.2713^{* *}$ & $0.3322 * *$ & $0.1293 * * *$ & $0.1326^{* * *}$ & $0.6514 * * *$ & $0.6678^{* * *}$ \\
\hline & $(7.47)$ & $(5.41)$ & $(-2.30)$ & $(-1.73)$ & $(2.25)$ & $(2.08)$ & $(7.09)$ & $(4.49)$ & $(7.57)$ & $(4.75)$ \\
\hline \multirow{2}{*}{ LIQ } & $0.0118^{* * *}$ & $0.0084^{* *}$ & $-0.3518^{* * *}$ & $-0.3202^{* * *}$ & $-0.1507^{* * *}$ & $-2.0400^{* * *}$ & $0.0112 * *$ & -0.0043 & $0.0398^{*}$ & -0.0141 \\
\hline & $(4.76)$ & $(2.17)$ & $(-9.64)$ & $(-4.87)$ & $(-3.28)$ & $(-3.27)$ & $(2.22)$ & $(-0.38)$ & $(1.86)$ & $(-0.27)$ \\
\hline \multirow{2}{*}{ KEELEY'S Q } & $-0.0394^{* * *}$ & $-0.0294^{* * *}$ & $0.4221^{* * *}$ & $0.4254^{* * *}$ & -0.0472 & 0.0144 & $-0.0886^{* * *}$ & $-0.0762^{* * *}$ & $-0.2965^{* * *}$ & $-0.2667^{* * *}$ \\
\hline & $(-5.76)$ & $(-3.05)$ & $(5.02)$ & $(3.54)$ & $(-0.60)$ & $(0.12)$ & $(-9.40)$ & $(-5.89)$ & $(-6.95)$ & $(-4.17)$ \\
\hline \multirow{2}{*}{ EFF } & -0.0037 & -0.0034 & 0.0860 & 0.1012 & $-0.4121^{* * *}$ & $-0.4472^{* * *}$ & -0.0114 & $-0.0227^{* *}$ & -0.0149 & -0.0553 \\
\hline & $(-1.15)$ & $(-0.54)$ & $(1.11)$ & $(0.98)$ & $(-8.24)$ & $(-3.52)$ & $(-1.63)$ & $(-2.01)$ & $(-0.56)$ & $(-1.21)$ \\
\hline \multirow{2}{*}{ BASERATE } & $0.0007^{* * *}$ & $0.0010^{* * *}$ & 0.0019 & 0.0020 & $0.0241^{* * *}$ & $0.0231^{* * *}$ & $0.0014^{* * *}$ & $0.0019 * * *$ & $0.0081^{* * *}$ & $0.0099 * * *$ \\
\hline & $(4.55)$ & $(4.25)$ & $(0.77)$ & $(0.70)$ & $(10.98)$ & $(9.92)$ & $(4.96)$ & $(5.02)$ & $(5.60)$ & $(5.46)$ \\
\hline \multirow{2}{*}{ GDP } & $-0.0126^{* * *}$ & -0.0083 & $0.1601^{* *}$ & $0.1696^{*}$ & $0.3763^{* * *}$ & $0.3818^{* * *}$ & 0.0046 & 0.0104 & 0.0344 & 0.0571 \\
\hline & $(-2.99)$ & $(-1.28)$ & $(2.29)$ & $(1.87)$ & $(5.88)$ & $(4.23)$ & $(0.63)$ & $(1.16)$ & $(0.90)$ & $(1.44)$ \\
\hline \multirow{2}{*}{ L\&O INDEX } & $0.0009^{*}$ & -0.0015 & 0.0049 & 0.0230 & $0.0314^{* * *}$ & -0.0120 & $0.0018^{* * *}$ & -0.0012 & 0.0054 & -0.0066 \\
\hline & $(1.83)$ & $(-1.41)$ & $(0.63)$ & $(1.51)$ & $(4.40)$ & $(-0.65)$ & $(2.81)$ & $(-0.63)$ & $(1.89)$ & $(-0.96)$ \\
\hline $\mathrm{N}$ & 899 & 899 & 899 & 899 & 899 & 899 & 899 & 899 & 899 & 899 \\
\hline$N$ (Banks) & 145 & 145 & 145 & 145 & 145 & 145 & 145 & 145 & 145 & 145 \\
\hline Adj. R2 & & 0.3899 & & 0.4101 & & 0.2517 & & 0.4004 & & 0.3005 \\
\hline R2-within & 0.3821 & 0.3960 & 0.4133 & 0.4160 & 0.2448 & 0.2592 & 0.3664 & 0.4064 & 0.2827 & 0.3075 \\
\hline R2-between & 0.3490 & 0.0034 & 0.5655 & 0.5138 & 0.3734 & 0.2098 & 0.1303 & 0.0084 & 0.2102 & 0.0648 \\
\hline R2-overall & 0.3790 & 0.1007 & 0.5447 & 0.5302 & 0.3396 & 0.2253 & 0.2733 & 0.0753 & 0.2102 & 0.1006 \\
\hline $\mathrm{F}$ & & $7.21 * * *$ & & $19.39 * * *$ & & $20.70^{* * *}$ & & $19.69 * * *$ & & $19.04 * * *$ \\
\hline \multicolumn{11}{|l|}{ Hausman Test } \\
\hline Prob>chi2 & & 48.87 & & 23.08 & & 43.65 & & 109.13 & & 29.66 \\
\hline chi2(9) & & 0.0000 & & 0.0060 & & 0.0000 & & 0.0000 & & 0.0005 \\
\hline
\end{tabular}

Note: ${ }^{*} \mathrm{p}<0.10,{ }^{* *} \mathrm{p}<0.05,{ }^{* *} \mathrm{p}<0.01$. The variables are calculated as follows. LLP $=$ Loan Loss provision / Total Loans, RWATA $=$ Risk-weighted Assets / Total Assets, INT_EXP $=$ Interest Expenses / Net Sales or Revenues, SD_DRET is the Standard Deviation of Daily Returns, SD_MRET is the Standard Deviation of Monthly Returns, CAP = Tier-1-Capital / Riskweighted Assets, ETA = Common Equity / Total Assets, SIZE = ln (Total Assets), LIQ = Total Investments / Total Assets, BADLOANS = Non-performing Loans / Total Assets, KEELEY’S $\mathrm{Q}=$ Market Capitalization + Total Liabilities / Total Assets, EFF = Non-interest expenses / Net Sales or Revenues, BASERATE is the national base rate, GDP the annual gross domestic product growth rate and L\&O INDEX the Law and Order Index published by the International Country Risk Guide. 
Table 6b. Regression results for accounting and market-based risk measures for the European bank market from 1992 to 2012

\begin{tabular}{|c|c|c|c|c|c|c|c|c|c|c|}
\hline \multirow{2}{*}{$\begin{array}{l}\text { Independent } \\
\text { variables }\end{array}$} & \multicolumn{2}{|c|}{ LLP (acc.) } & \multicolumn{2}{|c|}{ RWATA (acc.) } & \multicolumn{2}{|c|}{ INT_EXP (acc.) } & \multicolumn{2}{|c|}{ SD_DRET (mar.) } & \multicolumn{2}{|c|}{ SD_MRET (mar.) } \\
\hline & CAP & ETA & CAP & ETA & CAP & ETA & CAP & ETA & CAP & ETA \\
\hline \multirow{2}{*}{ CAP/ETA } & -0.0035 & $-0.0877^{* * *}$ & $-0.5092^{* * *}$ & $0.7259^{* * *}$ & $-0.1226^{*}$ & $-0.9001^{* * *}$ & 0.0029 & $-0.0933^{* *}$ & 0.0222 & -0.2431 \\
\hline & $(-0.51)$ & $(-2.90)$ & $(-3.41)$ & $(2.65)$ & $(-1.79)$ & $(-2.66)$ & $(0.82)$ & $(-2.23)$ & $(1.08)$ & $(-1.33)$ \\
\hline \multirow{2}{*}{ SIZE } & 0.0010 & 0.0010 & $-0.0470^{* * *}$ & $-0.0419^{* *}$ & 0.0239 & 0.0184 & $0.0071^{* * *}$ & $0.0070^{* * *}$ & $0.0270^{* * *}$ & $0.0262^{* * *}$ \\
\hline & $(1.08)$ & (1.15) & $(-2.83)$ & $(-2.23)$ & $(1.33)$ & (1.14) & $(3.94)$ & $(4.36)$ & $(2.97)$ & $(3.24)$ \\
\hline \multirow{2}{*}{ BADLOANS } & $0.1328^{* * *}$ & $0.1253^{* * *}$ & $-0.2490^{*}$ & -0.1772 & $0.3322^{* *}$ & 0.2676 & $0.1326^{* * *}$ & $0.1242^{* * *}$ & $0.6678^{* * *}$ & $0.6467^{* * *}$ \\
\hline & $(5.41)$ & $(5.16)$ & $(-1.73)$ & $(-0.94)$ & $(2.08)$ & $(1.51)$ & $(4.49)$ & $(4.20)$ & $(4.75)$ & $(4.57)$ \\
\hline \multirow{2}{*}{ LIQ } & $0.0084^{* *}$ & 0.0059 & $-0.3202^{* * *}$ & $-0.3399^{* * *}$ & $-0.2040^{* * *}$ & $-0.2228^{* * *}$ & -0.0043 & -0.0067 & -0.0141 & -0.0181 \\
\hline & $(2.17)$ & $(1.54)$ & $(-4.87)$ & $(-4.52)$ & $(-3.27)$ & $(-3.72)$ & $(-0.38)$ & $(-0.61)$ & $(-0.27)$ & $(-0.35)$ \\
\hline \multirow{2}{*}{ KEELEY'S Q } & $-0.0294^{* * *}$ & $-0.0254^{* * *}$ & $0.4254^{* * *}$ & $0.4492^{* * *}$ & 0.0144 & 0.0549 & $-0.0762^{* * *}$ & $-0.0744^{* * *}$ & $-0.2667^{* * *}$ & $-0.2622^{* * *}$ \\
\hline & $(-3.05)$ & $(-2.85)$ & $(3.54)$ & (3.74) & $(0.12)$ & (0.45) & $(-5.89)$ & $(-5.90)$ & $(-4.17)$ & $(-4.18)$ \\
\hline \multirow{2}{*}{ EFF } & -0.0034 & -0.0004 & 0.1020 & 0.0684 & $-0.4472^{* * *}$ & $-0.4383^{* * *}$ & $-0.0227^{* *}$ & -0.0183 & -0.0553 & -0.0486 \\
\hline & $(-0.54)$ & $(-0.09)$ & (0.98) & $(0.75)$ & $(-3.52)$ & $(-4.27)$ & $(-2.01)$ & $(-1.89)$ & $(-1.21)$ & $(-1.30)$ \\
\hline \multirow{2}{*}{ BASERATE } & $0.0010^{* * *}$ & $0.0008^{* * *}$ & 0.0020 & 0.0039 & $0.0231^{* * *}$ & $0.0220^{* * *}$ & $0.0019^{* * *}$ & $0.0016^{* * *}$ & $0.0099 * * *$ & $0.0092^{* * *}$ \\
\hline & $(4.25)$ & (3.58) & $(0.70)$ & $(1.47)$ & $(9.92)$ & (9.89) & $(5.02)$ & (4.33) & (5.46) & (5.03) \\
\hline \multirow{2}{*}{ GDP } & -0.0083 & $-0.0107^{*}$ & $0.1696^{*}$ & $0.1454^{*}$ & $0.3818^{* * *}$ & $0.3343^{* * *}$ & 0.0104 & 0.0075 & 0.0571 & 0.0480 \\
\hline & $(-1.28)$ & $(-1.79)$ & (1.87) & (1.76) & (4.23) & $(4.02)$ & (1.16) & (0.88) & (1.44) & (1.25) \\
\hline \multirow{2}{*}{ L\&O INDEX } & -0.0015 & -0.0009 & 0.0230 & 0.0189 & -0.0120 & -0.0055 & -0.0012 & -0.0004 & -0.0066 & $-0.0053^{* *}$ \\
\hline & $(-1.41)$ & $(-0.99)$ & $(1.51)$ & $(1.31)$ & $(-0.07)$ & $(-0.32)$ & $(-0.63)$ & $(-0.25)$ & $(-0.96)$ & $(-0.83)$ \\
\hline$N$ & 899 & 918 & 899 & 918 & 899 & 918 & 899 & 918 & 899 & 918 \\
\hline N (Banks) & 145 & 145 & 145 & 145 & 145 & 145 & 145 & 145 & 145 & 145 \\
\hline R2 & 0.3960 & 0.4192 & 0.4160 & 0.2935 & 0.2592 & 0.2784 & 0.4064 & 0.4191 & 0.3075 & 0.3122 \\
\hline Adj. R2 & 0.3899 & 0.4134 & 0.4101 & 0.2865 & 0.2517 & 0.2712 & 0.4004 & 0.4134 & 0.3005 & 0.3054 \\
\hline $\mathrm{F}$ & $7.21^{* * *}$ & $8.65^{* * *}$ & $19.39^{* * *}$ & $16.11^{* * *}$ & $20.70^{* * *}$ & $23.60^{* * *}$ & $19.69^{* * *}$ & 19.08 & 19.04 & $19.13^{* * *}$ \\
\hline
\end{tabular}

Note: ${ }^{\star} \mathrm{p}<0.10,{ }^{* *} \mathrm{p}<0.05,{ }^{* *} \mathrm{p}<0.01$. The variables are calculated as follows. LLP $=$ Loan Loss provision / Total Loan, RWATA = Risk-weighted Assets $/$ Total Assets, INT_EXP $=$ Interest Expenses / Net Sales or Revenues, SD_DRET is the Standard Deviation of Daily Returns, SD_MRET is the Standard Deviation of Monthly Returns, CAP = Tier-1 Capital / Risk-weighted Market Capitalization + Total Liabilities / Total Assets, EFF = Non-interest expenses / Net Sales or Revenues, BASERATE is the national base rate, GDP is the annual gross domestic product growth rate and L\&O INDEX is the Law and Order Index published by the International Country Risk Guide. 
Table 7a. Regression results for accounting and market-based profitability measures for the European bank market from 1992 to 2012

\begin{tabular}{|c|c|c|c|c|c|c|c|c|c|c|}
\hline \multirow{2}{*}{$\begin{array}{c}\text { Independent } \\
\text { variables }\end{array}$} & \multicolumn{2}{|c|}{ ROA } & \multicolumn{2}{|c|}{ PROFIT_MAR } & \multicolumn{2}{|c|}{ ROE } & \multicolumn{2}{|c|}{ M_DRET } & \multicolumn{2}{|c|}{ ARET } \\
\hline & $\mathbf{R E}$ & $\mathrm{FE}$ & RE & $\mathrm{FE}$ & $\mathbf{R E}$ & $\mathrm{FE}$ & $\mathbf{R E}$ & FE & RE & $\mathrm{FE}$ \\
\hline \multirow{2}{*}{ CAP } & $0.0076 * * *$ & 0.0057 & $0.1077^{* * *}$ & 0.0588 & 0.0429 & 0.0119 & 0.0006 & $0.0014^{* *}$ & $0.1792 *$ & $0.2811^{* *}$ \\
\hline & $(3.16)$ & $(0.89)$ & $(4.03)$ & $(0.72)$ & $(1.54)$ & $(0.23)$ & $(1.34)$ & $(2.28)$ & $(1.72)$ & $(2.26)$ \\
\hline \multirow{2}{*}{ SIZE } & 0.0004 & -0.0005 & $0.0083^{*}$ & 0.0135 & $0.0210^{* * *}$ & -0.0194 & 0.0000 & $-0.0004^{*}$ & -0.0085 & $-0.0999^{* *}$ \\
\hline & $(1.20)$ & $(-0.44)$ & $(1.81)$ & $(0.86)$ & $(4.38)$ & $(-1.14)$ & $(-0.70)$ & $(-1.96)$ & $(-0.98)$ & $(-2.26)$ \\
\hline \multirow{2}{*}{ BADLOANS } & $-0.1132 * * *$ & $-0.1153 * * *$ & $-1.8912^{* * *}$ & $-1.9144^{* * *}$ & $-1.6559^{* * *}$ & $-1.6017^{* * *}$ & 0.0037 & 0.0022 & $-1.0870^{* *}$ & 0.1356 \\
\hline & $(-7.31)$ & $(-4.48)$ & $(-7.57)$ & $(-4.69)$ & $(-4.68)$ & $(-3.69)$ & $(-1.48)$ & $(0.63)$ & $(-2.26)$ & $(0.17)$ \\
\hline \multirow{2}{*}{ LIQ } & -0.0031 & 0.0020 & $-0.0867^{*}$ & -0.0200 & $-0.1303^{* *}$ & -0.0494 & $0.0014^{* *}$ & $0.0034^{* * *}$ & $0.2916^{* *}$ & $0.7796^{* * *}$ \\
\hline & $(-1.09)$ & $(0.37)$ & $(-1.72)$ & $(-0.20)$ & $(-2.09)$ & $(-0.46)$ & $(2.53)$ & $(4.22)$ & $(2.23)$ & $(3.99)$ \\
\hline \multirow{2}{*}{ KEELEY'S Q } & $0.0057 * * *$ & $0.0583 * * *$ & $0.8513^{* * *}$ & $0.8747^{* * *}$ & $0.9081^{* * *}$ & $0.8572^{* * *}$ & $0.0139^{* * *}$ & $0.0157^{* * *}$ & $3.4843^{* * *}$ & $3.9848^{* * *}$ \\
\hline & $(9.44)$ & $(5.85)$ & $(8.46)$ & $(5.55)$ & $(7.85)$ & $(5.85)$ & $(10.94)$ & $(7.90)$ & $(11.94)$ & $(9.63)$ \\
\hline \multirow{2}{*}{ EFF } & $0.0086^{* * *}$ & 0.0085 & $0.1160^{* *}$ & $0.1935^{*}$ & $0.1681^{* *}$ & 0.1523 & $0.0014 * *$ & $0.0053^{* * *}$ & $0.3292^{* * *}$ & $1.0949^{* * *}$ \\
\hline & $(2.99)$ & $(1.40)$ & $(2.40)$ & $(1.92)$ & $(2.42)$ & $(1.10)$ & $(2.39)$ & $(4.27)$ & $(2.65)$ & $(4.29)$ \\
\hline \multirow{2}{*}{ BASERATE } & 0.0001 & 0.0000 & -0.0042 & -0.0019 & -0.0015 & -0.0040 & $0.0001^{*}$ & $0.0001^{* *}$ & 0.0128 & $0.0181^{*}$ \\
\hline & $(0.37)$ & $(0.01)$ & $(-1.57)$ & $(-0.46)$ & $(-0.44)$ & $(-1.10)$ & $(1.74)$ & $(2.31)$ & $(1.46)$ & $(1.68)$ \\
\hline \multirow{2}{*}{ GDP } & -0.0023 & -0.0025 & -0.0666 & -0.0712 & 0.0910 & 0.0735 & $-0.0045^{* * *}$ & $-0.0033^{* * *}$ & $-0.9263^{* * *}$ & $-0.7008^{* *}$ \\
\hline & $(-0.49)$ & $(-0.42)$ & $(-0.84)$ & $(-0.77)$ & $(0.96)$ & $(0.63)$ & $(-4.61)$ & $(-3.19)$ & $(-4.23)$ & $(2.49)$ \\
\hline \multirow{2}{*}{ L\&O INDEX } & 0.0004 & $0.0025 * *$ & 0.0055 & $0.0339 * *$ & $0.0178^{* *}$ & $0.0552 * * *$ & 0.0000 & -0.0002 & -0.0035 & -0.0638 \\
\hline & $(0.83)$ & $(2.45)$ & $(0.79)$ & $(2.10)$ & $(2.25)$ & (3.15) & $(0.09)$ & $(-1.06)$ & $(-0.21)$ & $(-1.22)$ \\
\hline N & 909 & 909 & 909 & 909 & 909 & 909 & 909 & 909 & 909 & 909 \\
\hline$N($ Banks) & 145 & 145 & 145 & 145 & 145 & 145 & 145 & 145 & 145 & 145 \\
\hline Adj. R2 & & 0.3648 & & 0.3611 & & 0.2645 & & 0.2378 & & 0.2723 \\
\hline R2-within & 0.3658 & 0.3711 & 0.3618 & 0.3674 & 0.2622 & 0.2717 & 0.2096 & 0.2453 & 0.2477 & 0.2795 \\
\hline R2-between & 0.3261 & 0.1996 & 0.3343 & 0.2468 & 0.3318 & 0.0352 & 0.1950 & 0.0559 & 0.3218 & 0.0785 \\
\hline R2-overall & 0.3883 & 0.32 & 0.3858 & 0.3215 & 0.3279 & 0.1298 & 0.2965 & 0.1050 & 0.2245 & 0.1256 \\
\hline F & & $14.27^{* * *}$ & & $12.15^{* * *}$ & & $17.61^{* * *}$ & & $28.83^{* * *}$ & & $29.87^{* * *}$ \\
\hline \multicolumn{11}{|l|}{ Hausman Test } \\
\hline Prob $>$ chi 2 & & 10.08 & & 11.98 & & 15.07 & & 66.25 & & 66.63 \\
\hline chi2(9) & & 0.3444 & & 0.2144 & & 0.0890 & & 0.0000 & & 0.0000 \\
\hline
\end{tabular}

Note: $0.10{ }^{* *} \mathrm{p}<0.05,{ }^{* * *} \mathrm{p}<0.01$. The variables are calculated as follows. ROA $=$ Net Income $/$ Total Assets, PROFIT_MAR $=$ Net Income $/$ Net Sales or Revenues, ROE $=$ Net Income $/$ Common Equityt-1, the variable M DRET is the average Daily Return per fiscal year and firm, ARET is the Annual Return, CAP = Tier-1 Capital $/$ Risk-weighted Assets, ETA = Common Equity / Total Assets, SIZE = ln (Total Assets), LIQ = Total Investments / Total Assets, BADLOANS = Non-performing Loans / Total Assets, KEELEY'S Q = Market Capitalization + Total Liabilities / Total Assets, EFF = Non-interest expenses / Net Sales or Revenues, BASERATE is the national base rate, GDP is the annual gross domestic product growth rate and L\&O 
Table 7b. Regression results for accounting and market-based profitability measures for the European bank market from 1992 to 2012

\begin{tabular}{|c|c|c|c|c|c|c|c|c|c|c|}
\hline \multirow{2}{*}{$\begin{array}{l}\text { Independent } \\
\text { variables }\end{array}$} & \multicolumn{2}{|c|}{ ROA } & \multicolumn{2}{|c|}{ PROFIT_MAR } & \multicolumn{2}{|c|}{ ROE } & \multicolumn{2}{|c|}{ M_DRET } & \multicolumn{2}{|c|}{ ARET } \\
\hline & CAP & ETA & CAP & ETA & CAP & ETA & CAP & ETA & CAP & ETA \\
\hline \multirow{2}{*}{ CAP/ETA } & $0.0076^{* * *}$ & $0.1480^{* * *}$ & $0.1077^{* * *}$ & $2.0440^{* * *}$ & 0.0429 & $1.0556^{* * *}$ & $0.0014^{* *}$ & 0.0031 & $0.2811^{* *}$ & 0.5121 \\
\hline & (3.16) & (8.85) & $(4.03)$ & $(8.24)$ & $(1.54)$ & (3.15) & $(2.28)$ & $(0.93)$ & $(2.26)$ & (0.59) \\
\hline \multirow{2}{*}{ SIZE } & 0.0004 & $0.0010^{* * *}$ & $0.0083^{*}$ & $0.0185^{* * *}$ & $0.0210^{* * *}$ & $0.0211^{* * *}$ & $-0.0004^{*}$ & $-0.0004^{*}$ & $-0.0999 * *$ & $-0.0928^{* *}$ \\
\hline & $(1.20)$ & $(4.17)$ & $(1.81)$ & $(4.85)$ & $(4.38)$ & $(4.86)$ & $(-1.96)$ & $(-1.82)$ & $(-2.26)$ & $(-1.98)$ \\
\hline \multirow{2}{*}{ BADLOANS } & $-0.1132 * * *$ & $-0.1039 * * *$ & $-1.8912^{* * *}$ & $-1.7672^{* * *}$ & $-1.6559 * * *$ & $-1.6843^{* * *}$ & $0.0022^{* * *}$ & -0.0002 & 0.1356 & -0.2952 \\
\hline & $(-7.31)$ & $(-6.99)$ & $(-7.57)$ & $(-7.33)$ & $(-4.68)$ & $(-5.23)$ & $(0.63)$ & $(-0.05)$ & $(0.17)$ & $(-0.33)$ \\
\hline \multirow{2}{*}{ LIQ } & -0.0031 & 0.0000 & $-0.0867^{*}$ & -0.0490 & $-0.1303^{* *}$ & -0.0725 & $0.0034^{* * *}$ & $0.0018^{* *}$ & $0.7796^{* * *}$ & $0.3820^{* *}$ \\
\hline & $(-1.09)$ & $(0.02)$ & $(-1.72)$ & $(-1.06)$ & $(-2.09)$ & $(-1.26)$ & $(4.22)$ & $(2.33)$ & (3.99) & $(2.04)$ \\
\hline \multirow{2}{*}{ KEELEY'S Q } & $0.0057^{* * *}$ & $0.0359^{* * *}$ & $0.8513^{* * *}$ & $0.5342^{* * *}$ & $0.9081^{* * *}$ & $0.6183^{* * *}$ & $0.0157^{* * *}$ & $0.0119^{* * *}$ & $3.9848^{* * *}$ & $3.1068^{* * *}$ \\
\hline & $(9.44)$ & $(2.87)$ & (8.46) & $(2.97)$ & $(7.85)$ & $(3.22)$ & $(7.90)$ & $(4.10)$ & $(9.63)$ & $(4.51)$ \\
\hline \multirow{2}{*}{ EFF } & $0.0086^{* * *}$ & 0.0026 & $0.1160^{* *}$ & 0.0351 & $0.1681^{* *}$ & 0.0880 & $0.0053^{* * *}$ & $0.0040^{* * *}$ & $1.0949^{* * *}$ & $0.8470^{* * *}$ \\
\hline & $(2.99)$ & (1.08) & $(2.40)$ & $(0.94)$ & $(2.42)$ & $(1.45)$ & $(4.27)$ & $(3.73)$ & $(4.29)$ & $(3.88)$ \\
\hline \multirow{2}{*}{ BASERATE } & 0.0001 & $0.0004^{* * *}$ & -0.0042 & 0.0006 & -0.0015 & 0.0032 & $0.0001^{* *}$ & 0.0000 & $0.0181^{*}$ & 0.0039 \\
\hline & $(0.37)$ & (3.33) & $(-1.57)$ & $(0.31)$ & $(-0.44)$ & (1.28) & $(2.31)$ & (0.88) & (1.68) & $(0.45)$ \\
\hline \multirow{2}{*}{ GDP } & -0.0023 & $0.0097^{* *}$ & -0.0666 & 0.0932 & 0.0910 & $0.2519^{* * *}$ & $-0.0033^{* * *}$ & $-0.0034^{* * *}$ & $-0.7008^{* *}$ & $-0.7496^{* * *}$ \\
\hline & $(-0.49)$ & $(2.43)$ & $(-0.84)$ & $(1.40)$ & $(0.96)$ & $(2.90)$ & $(-3.19)$ & $(-4.06)$ & $(-2.49)$ & $(-3.27)$ \\
\hline \multirow{2}{*}{ L\&O INDEX } & 0.0004 & 0.0003 & 0.0055 & 0.0005 & $0.0178^{* *}$ & 0.0087 & 0.0002 & $-0.0003^{* * *}$ & -0.0638 & $-0.0921^{* * *}$ \\
\hline & $(0.83)$ & $(0.99)$ & $(0.79)$ & $(0.10)$ & $(2.25)$ & (1.64) & $(-1.06)$ & $(-4.41)$ & $(-1.22)$ & $(-4.71)$ \\
\hline N & 909 & 1180 & 909 & 1180 & 909 & 1180 & 909 & 1180 & 909 & 1180 \\
\hline N (Banks) & 145 & 145 & 145 & 145 & 145 & 145 & 145 & 145 & 145 & 145 \\
\hline Adj. R2 & & & & & & & 0.2378 & 0.1869 & 0.2723 & 0.215 \\
\hline R2-within & 0.3658 & 0.4259 & 0.3618 & 0.4041 & 0.2622 & 0.2387 & & & & \\
\hline R2-between & 0.3261 & 0.5154 & 0.3343 & 0.4603 & 0.3318 & 0.4201 & & & & \\
\hline R2-overall & 0.3883 & 0.4449 & 0.3858 & 0.4115 & 0.3279 & 0.2966 & & & & \\
\hline $\mathrm{F}$ & & & & & & & $28.83^{* * *}$ & $22.18^{* * *}$ & $29.87^{* * *}$ & $22.14^{* * *}$ \\
\hline
\end{tabular}

Note: ${ }^{\star} 0.10,{ }^{* *} \mathrm{p}<0.05,{ }^{* * *} \mathrm{p}<0.01$. The variables are calculated as follows. ROA $=$ Net Income $/$ Total Assets, PROFIT_MAR $=$ Net Income $/$ Net Sales or Revenues, ROE $=$ Net Income / Common Equity , the variable M_DRET is the average Daily Return per fiscal year and firm, ARET is the Annual Return, CAP = Tier-1 Capital $/$ Risk-weighted Assets, ETA $=$ Common Equity / Total Assets, SIZE = ln (Total Assets), LIQ = Total Investments / Total Assets, BADLOANS = Non-performing Loans / Total Assets, KEELEY'S Q = Market Capitalization + Total Liabilities / Total Assets, EFF = Non-interest expenses / Net Sales or Revenues, BASERATE is the national base rate, GDP is the annual gross domestic product growth rate and L\&O INDEX is the Law and Order Index published by the International Country Risk Guide. 